\title{
THE IMPACT OF TRADE CONFLICT ON DEVELOPING ASIA
}

Abdul Abiad, Kristina Baris, John Arvin Bernabe, Donald Jay Bertulfo, Shiela Camingue-Romance, Paul Neilmer Feliciano, Mahinthan Joseph Mariasingham, and Valerie Mercer-Blackman

\section{NO. 566}

December 2018
ADB ECONOMICS WORKING PAPER SERIES 
ADB Economics Working Paper Series

\section{The Impact of Trade Conflict on Developing Asia}

\begin{abstract}
Abdul Abiad, Kristina Baris, John Arvin Bernabe, Donald Jay Bertulfo, Shiela Camingue-Romance, Paul Neilmer Feliciano, Mahinthan Joseph Mariasingham, and Valerie Mercer-Blackman
\end{abstract}

No. 566 | December 2018
Abdul Abiad (aabiad@adb.org) is an economic advisor; Mahinthan Joseph Mariasingham

(mmariasingham@adb.org) is a statistician; Valerie Mercer-Blackman (vmercerblackman@adb.org) is a senior economist; Shiela Camingue-Romance (scamingue@adb.org) is an economics officer; Kristina Baris (kbaris.consultant@adb.org), John Arvin Bernabe (jbernabe.consultant@adb.org), Donald Jay Bertulfo (dbertulfo.consultant@adb.org), and Paul Neilmer Feliciano (pfeliciano.consultant@adb.org) are consultants from the Economic Research and Regional Cooperation Department (ERCD) of the Asian Development Bank.

The analysis in this paper was used in the Asian Development Outlook 2018 Update. The team would like to thank participants at the ERCD Seminar Series for valuable comments. All remaining errors are our own. 
(C) 2019 Asian Development Bank 6 ADB Avenue, Mandaluyong City, 1550 Metro Manila, Philippines

Tel +632632 4444; Fax +6326362444

www.adb.org

Some rights reserved. Published in 2019.

ISSN 2313-6537 (print), 2313-6545 (electronic)

Publication Stock No. WPS189770-2

DOI: http://dx.doi.org/10.22617/WPS189770-2

The views expressed in this publication are those of the authors and do not necessarily reflect the views and policies of the Asian Development Bank (ADB) or its Board of Governors or the governments they represent.

ADB does not guarantee the accuracy of the data included in this publication and accepts no responsibility for any consequence of their use. The mention of specific companies or products of manufacturers does not imply that they are endorsed or recommended by ADB in preference to others of a similar nature that are not mentioned.

By making any designation of or reference to a particular territory or geographic area, or by using the term "country" in this document, $A D B$ does not intend to make any judgments as to the legal or other status of any territory or area.

This work is available under the Creative Commons Attribution 3.0 IGO license (CC BY 3.0 IGO)

https://creativecommons.org/licenses/by/3.o/igo/. By using the content of this publication, you agree to be bound by the terms of this license. For attribution, translations, adaptations, and permissions, please read the provisions and terms of use at https://www.adb.org/terms-use\#openaccess.

This CC license does not apply to non-ADB copyright materials in this publication. If the material is attributed to another source, please contact the copyright owner or publisher of that source for permission to reproduce it. $\mathrm{ADB}$ cannot be held liable for any claims that arise as a result of your use of the material.

Please contact pubsmarketing@adb.org if you have questions or comments with respect to content, or if you wish to obtain copyright permission for your intended use that does not fall within these terms, or for permission to use the ADB logo.

Corrigenda to ADB publications may be found at http://www.adb.org/publications/corrigenda.

Notes:

In this publication, “\$” refers to United States dollars.

ADB recognizes "China" as the People's Republic of China.

The ADB Economics Working Paper Series presents data, information, and/or findings from ongoing research and studies to encourage exchange of ideas and to elicit comment and feedback about development issues in Asia and the Pacific. Since papers in this series are intended for quick and easy dissemination, the content may or may not be fully edited and may later be modified for final publication. 


\section{CONTENTS}

TABLES AND FIGURES

ABSTRACT $v$ V

$\begin{array}{ll}\text { I. INTRODUCTION } & 1\end{array}$

II. THE 2018 TRADE CONFLICT UNFOLDS 2

III. THEMODEL SET UP $\quad 5$

A. Channels of Impact 5

B. Trade Conflict Scenarios 5

C. Data and Scenario Modeling 6

D. Input-Output Analysis 10

E. Comparison with Other Analyses of the Trade Conflict 11

IV. RESULTS $\quad 12$

A. Effects on Gross Domestic Product $\quad 12$

B. Effects of Exports $\quad 15$

C. Effects on Employment 19

D. Effects on Current Account Balances 22

$\begin{array}{lll}\text { V. SENSITIVITY ANALYSIS } & 24\end{array}$

VI. $\quad$ CONCLUDING REMARKS 26

$\begin{array}{lr}\text { APPENDIX } & 29\end{array}$

$\begin{array}{ll}\text { REFERENCES } & 37\end{array}$ 


\section{TABLES, FIGURES, AND BOX}

\section{TABLES}

1 Timing Calculations for Direct Effects Based on Tariffs' Dates of Effectivity 6

2 Description and Size of Modeled Scenarios 9

3 Employment Effects under Worse-Case Scenario, Selected Economies 21

$4 \quad$ Description of Elasticity Assumptions 24

$5 \quad$ Results of Robustness Checks by Type of Elasticity Assumption 25

A1 Total Bilateral Trade Affected by the Implemented and Proposed Tariff Lines 29

A2 Summary of Literature on United States-People's Republic of China Trade Conflict 32

A3 Summary of Impact of Trade Conflict under Each Scenario, Developing Asia 35

\section{FIGURES}

1 Chronology of the Trade Conflict as of End-October $2018 \quad 2$

2 Global Production Chains 3

3 Impact of the Trade Conflict on Gross Domestic Product, by Scenario 14

$4 \quad$ Sectoral Impact of Current Scenario 15

$5 \quad$ Impact on Exports, by Country 16

6 Developing Asia: Impact on Electrical and Optical Equipment Exports 18

$7 \quad$ Developing Asia: Impact on Textile and Garment Exports 19

8 Impact on Employment, by Country 20

9 Current Account Balance under Trade Conflict Scenarios 23

10 United States-People's Republic of China Trade Balance Under Trade Conflict Scenarios

BOX

Factor Adjustments Made to Generate Product-Level Elasticities 


\begin{abstract}
This paper analyzes the effects of the current trade conflict on developing Asia using the Asian Development Bank's Multiregional Input-Output Table (MRIOT), allowing us to calculate the impact on individual countries and on sectors within countries. The analysis estimates the direct impact on all tariff-affected goods; uses input-output analysis to estimate indirect effects on gross domestic product (GDP), exports, and employment; and allows for redirection of trade toward other producers using the approach of Feenstra and Sasahara (2017). A full escalation of the bilateral United States (US)-People's Republic of China (PRC) trade conflict would shave $1 \%$ off PRC GDP and $0.2 \%$ off US GDP. The rest of developing Asia could see small net gains thanks to trade redirection, particularly in the electronics sector. A trade war in autos and parts would hurt the European Union and Japan. The conflict has substantial negative effects on PRC and US employment, but only minor impacts on current account balances.
\end{abstract}

Keywords: exports, input-output, international trade, tariffs, trade conflict, trade redirection

JEL codes: E00, F13, F14, O47 


\section{INTRODUCTION}

In an era where manufacturing has become a global endeavor and international trade has driven growth and prosperity in Asia, the trade conflict that broke out in early 2018 presents a major stumbling block. The two main protagonists, the United States (US) and the People's Republic of China (PRC), are the world's largest economies and traders, together accounting for two-fifths of global gross domestic product (GDP) and about a quarter of global trade. Further, the trade conflict is not just bilateral but global, with many countries hit by the first wave of tariffs on steel, aluminum, washing machines, and solar panels and retaliating against them, even as a new wave of tariffs is threatened against auto and auto parts. It is therefore important to understand and quantify the risks to Asian economies posed by the measures already implemented, as well as those that may follow. Underlying Asia's growth strategy was an assumption that free trade provided the opportunity to benefit from ever longer global value chains, where each production unit is built to minimize costs, maximize efficiency, and foster innovation through international partnerships.

This is the first study to examine the current trade conflict using the Asian Development Bank's Multiregional Input-Output Tables, a rich dataset capturing international input-output linkages. It allows us to incorporate the strong trade and production links within developing Asia and between the region and the rest of the world, which is important given that trade in intermediate products and capital goods comprise $81 \%$ of developing Asia's total trade in 2017 . The paper looks at different scenarios by first using calibrated elasticities to compute for the direct impact of the trade conflict on all tariff-affected goods, then conducting an input-output analysis to estimate the indirect effect of tariffs on GDP, exports, and employment not just globally and regionally, but also on individual countries and sectors within countries. Finally, the impacts of trade redirection toward other producers are analyzed using the input-output based approach adopted by Feenstra and Sasahara (2017).

Results show that the negative effects are small for all the implemented and proposed tariff measures up to mid-October 2018, reducing PRC GDP by $0.5 \%$ and US GDP by $0.1 \%$ over $2-3$ years. A full US-PRC bilateral escalation would shave just over $1 \%$ off PRC's GDP and $0.2 \%$ off US GDP. If all documented threats and retaliations are carried out (namely, 25\% tariffs on all bilateral trade between the US and the PRC, and 25\% tariffs on auto and parts imports by the US, assuming it will be fully retaliated against), the impact on the global economy can be significant as other advanced economies (such as the European Union [EU] and Japan) will suffer as well. Interestingly, trade redirection could generate a small net positive impact on other Asian economies, particularly electronics producers. The results in this paper are in line with those that have examined the trade conflict using a general equilibrium approach (Bollen and Rojas-Romagosa 2018; IMF 2018b; Kutlina-Dimitrova and Lakatos 2017), but provide a more granular analysis of individual countries and sectors. Moreover, the inputoutput framework allows us to quantify forward and backward linkages which are missing in other papers.

In section II, the paper discusses the chronology of the 2018 trade conflict. Section III describes our data and methodology, and how it compares to other recent models in the literature. Section IV reports the main findings and provides estimates of the impact on the region's trade and current account balances in 2018 and 2019. Section V performs some sensitivity analysis around the estimates and considers extensions and caveats of the methodology, such as the timing effects, uncertainty regarding the amount of trade redirection, and rebalancing of supply and demand in labor and other markets. Section VI summarizes with a few concluding remarks. 


\section{THE 2018 TRADE CONFLICT UNFOLDS}

The first salvoes of the trade conflict occurred in the first quarter of 2018. On 22 January, the US imposed $20 \%$ tariffs on imports of large residential washing machines and $30 \%$ on solar panels, and on 23 March, it imposed 25\% tariffs on imports of steel and 10\% tariffs on aluminum. Together these tariffs affected $\$ 58.3$ billion worth of goods (Figure 1). The economies that were hit-Canada, the EU, Mexico, the Russian Federation, Turkey, and, in developing Asia, India and the PRC-retaliated with their own tariffs affecting $\$ 35.8$ billion of US exports. The direct impact of these initial measures on developing Asia was small, as they only affected less than $0.1 \%$ of the region's exports.

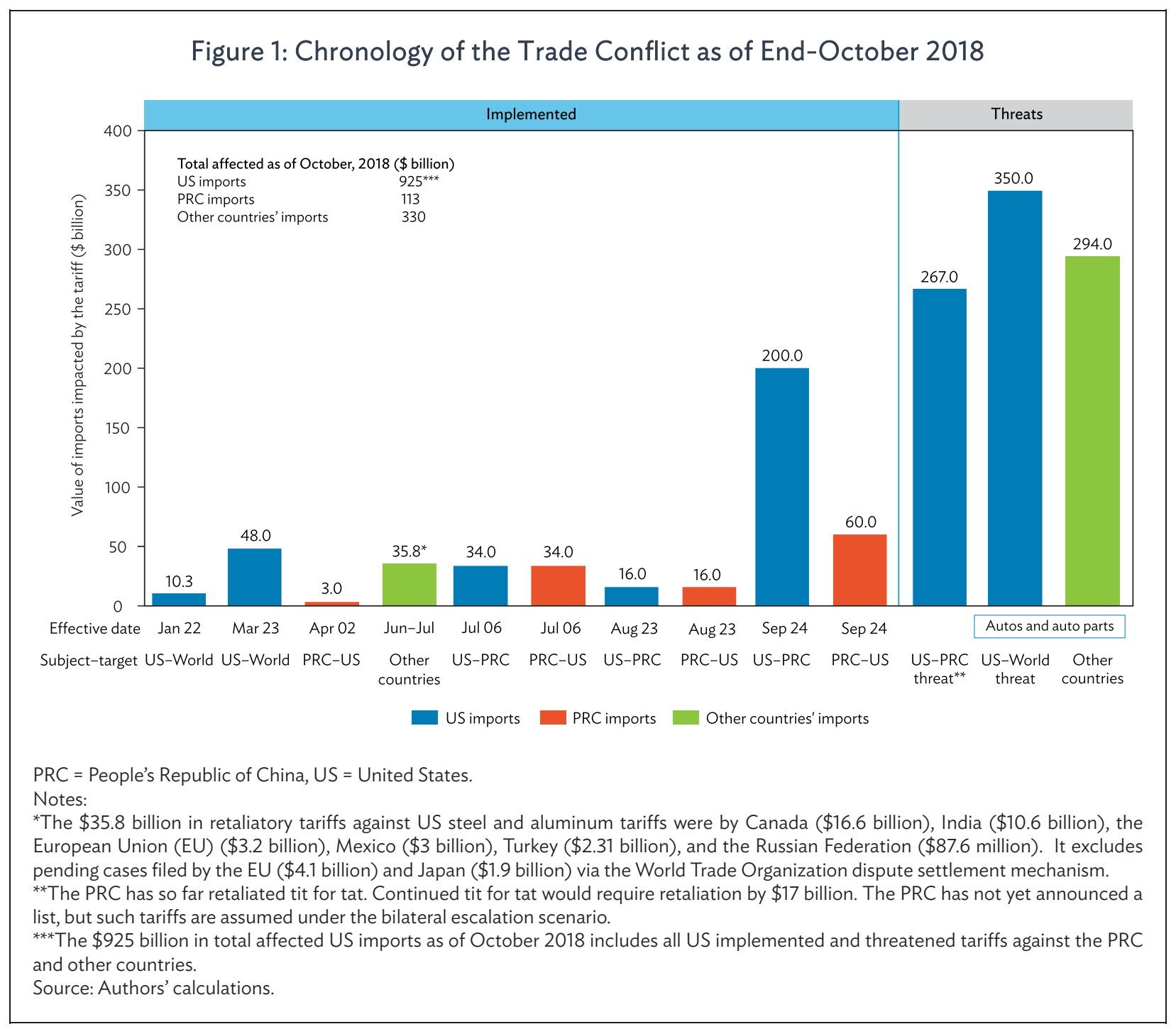

The conflict escalated and became more bilateral in nature in the second and third quarters of 2018. The US imposed, in two steps, tariffs on a wide range of imports from the PRC worth $\$ 50$ billion: $\$ 34$ billion on 6 July and another \$16 billion on 23 August. The PRC immediately retaliated with tariffs on an equal amount of imports from the US. On 24 September, an additional $\$ 200$ billion of PRC imports were hit with a $10 \%$ tariff scheduled to increase to $25 \%$ in January 2019 . The PRC retaliated with tariffs of $5 \%-10 \%$ on $\$ 60$ billion worth of imports from the US, effective the same day. The 
smaller amount reflected the fact that the PRC imports only about $\$ 130$ billion in goods from the US, with almost $90 \%$ subject to tariffs as of 23 September 2018. In comparison, the US imported $\$ 505$ billion in goods from the PRC in 2017. This bilateral trade conflict is worrisome for both the region and the world, as the PRC and the US are two of the three main hubs for global production chains (Figure 2), with tight trade links in key sectors such as electronics and high-technology equipment.

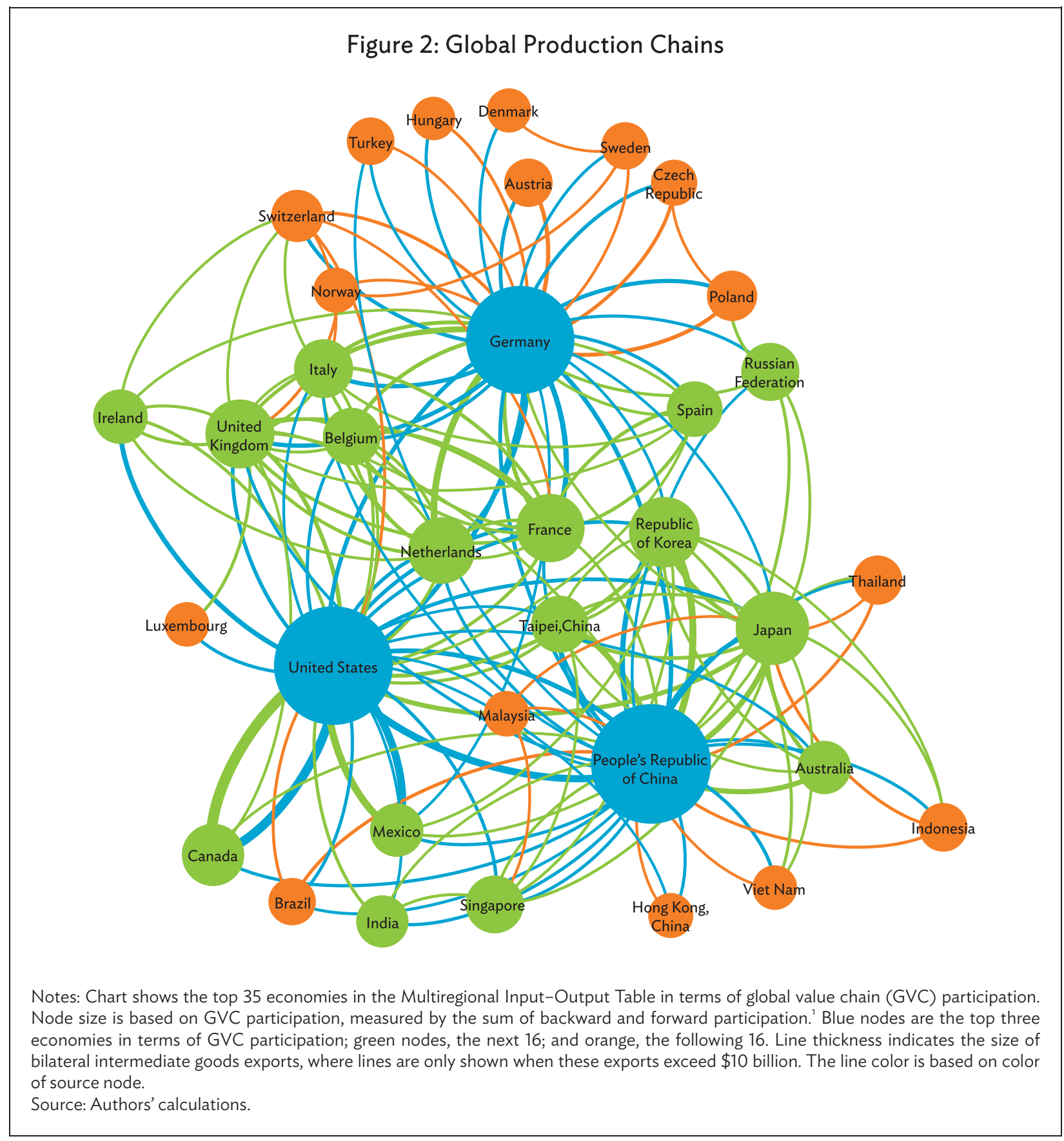

Forward participation is measured by the share of an economy's domestic value-added content embodied in the exports of other countries, while backward participation is measured by the share of foreign value-added content embodied in an economy's exports, following the Wang, Wei, and Zhu (2018) decomposition of gross exports. See the Technical Appendix in Part IV of ADB (2015) for further details and technical definitions of these concepts. 
Most of the products affected in the first two rounds of bilateral tariffs levied on the PRC (worth $\$ 50$ billion) are capital and intermediate goods that are targeted to benefit from the PRC's "Made in China 2025" plan. The PRC imposed tariffs mostly on agricultural products (including soybean meal and pork), chemicals, medical equipment, and energy equipment. These are more homogeneous goods available in other markets and are globally priced. The global stock-to-use ratios of steel and soybeans at the time of the tariff imposition were also at very comfortable levels. ${ }^{2}$ In contrast, the US imposed tariffs mostly on machinery, transport equipment, and other industrial parts, goods that tend to be deeply immersed in global value chains (See Appendix Table A1). By the time trade tensions escalated to the second round of $\$ 200$ billion by the US and $\$ 60$ billion tariffs by the PRC, the affected product lines grew in scope such that it inevitably delved into consumer goods since fewer supply chain lines were left to target.

Continued threats of even more trade measures, both bilateral and global, portend even greater escalation. On the bilateral front, the US has begun vetting tariffs on another $\$ 267$ billion of imports from the PRC that, should they go into effect, would effectively mean all goods exported from the PRC to the US are subject to the tariff. The PRC has threatened to retaliate with similar tariffs on all its merchandise imports from the US and is considering other avenues for retaliation. On the global front, the US administration has submitted for consideration a 25\% tariff on US imports of autos and auto parts from all trading partners, which would affect $\$ 350$ billion worth of goods. Here as well, the European Commission indicated in a report that retaliatory tariffs by other countries would reach up to $\$ 294$ billion worth of US exports.

The escalation and threats have significantly dampened the outlook for global growth over the medium term. Both global growth and developing Asian growth have been revised down for 2019 by the International Monetary Fund (IMF) and ADB as a result of the impact of the trade conflict (IMF 2018a and ADB 2018b). Moreover, data in the third quarter of 2018 already show signs of weaker export and sales in the PRC. The threats have also placed investors in a wait-and-see mode, accelerated restrictions of high-tech foreign direct investment from the PRC and vice-versa (Hanemann 2018); and incited complaints from global multinational companies regarding major disruptions to their businesses (Reuters 2018).

As concern over collateral damage from the US-PRC trade dispute continues, other economies have called for stronger trade ties, which can help cushion the impact. Free trade agreements pushing ahead within Asia include the Asia-Pacific Trade Agreement, the Comprehensive and Progressive Agreement for Trans-Pacific Partnership, and the Regional Comprehensive Economic Partnership, which comprises the largest trading block in the region, including both the PRC and India. Outside Asia, the EU has recently signed an agreement with Japan on the Japan-EU Economic Partnership Agreement, which represents the biggest bilateral trade deal by the EU. Moreover, the EU has also reached a deal with Singapore on the EU-Singapore Free Trade Agreement and has agreed with the US on the EU-US zero tariff deal. The US has also initiated less threatening negotiations: recently, a new deal, called the US-Canada-Mexico Agreement, has been reached by Canada, Mexico, and the US. The US also reinitiated trade talks with the EU. Nonetheless, the environment continues

2 Although soybeans can be substituted with supplies from other countries, in principle, future contracts for delivery of agricultural goods are set ahead of time, which implies that severed contracts create significant disruptions. Indeed, pork farmers in the PRC reportedly have found it difficult to replace the same quality of soybean meal for animal feed, impacting pork prices. Following protests by US soybean farmers regarding the ensuing losses from tariffs imposed by the PRC, the US government announced a subsidy program to buy the amounts not purchased by the PRC and massively increase food aid under the Food Stamp program. Such a redirection is highly inefficient. 
to be very uncertain, and already this situation is affecting business plans. It is thus important to understand the underlying effects at the sector level.

\section{THE MODEL SET UP}

\section{A. Channels of Impact}

There are various channels through which the trade conflict can affect economies in developing Asia. The analysis presented here focuses on three possible channels:

(i) Direct effects impact products and countries that are subject to the tariffs. Purchasers of these goods in the country that imposed the tariff now face higher prices per unit, which reduces their demand for these products from the targeted countries.

(ii) Indirect effects work through local and international supply chains. Producers that now sell fewer goods because of the tariffs respond by lowering production and buying fewer intermediate inputs from their suppliers, both domestic and foreign, with knock-on effects all the way along local and international supply chains.

(iii) Trade redirection is possible toward suppliers not directly affected by the tariffs. These suppliers can be either domestic or in third countries that are exempt from the tariffs. Trade redirection may thus benefit other countries not directly involved in the trade conflict. This is particularly true for countries that already produce the targeted goods but are exempted from the tariffs now levied on their competitors, and which have the capacity to expand production sufficiently in response to increased demand. It may also benefit the countries to which production may shift in a prolonged trade conflict.

These three channels partially capture the short- to medium-term disruptions on firms and consumers, particularly for items, such as semiconductors, that are produced by relatively long and complex global value chains. The direct effect captures the immediate impact of the trade conflict. In the short term, countries imposing the tariff experience lower product imports from the rest of the world. Production of, and demand for, final products will also be affected as inputs become more expensive, leading to a reduction in output. Because producers and consumers may need more time and resources to find alternative suppliers, trade redirection is assumed to occur in the medium term. Both the domestic economy and third countries that produce the same goods targeted by tariffs could experience a net benefit as the demand for their output rises owing to trade and production redirection.

\section{B. Trade Conflict Scenarios}

The implications of three separate trade conflict scenarios are examined. The first scenario ("current scenario') is the trade conflict as it currently stands, which includes all trade measures implemented as of October 2018. For the $\$ 200$ billion in tariffs that the US imposed on the PRC, a $25 \%$ rate is assumed because the US has already declared that the tariff will rise to this level by January 2019. The second scenario ('bilateral escalation scenario') features the US-PRC full-blown escalation, with the trade conflict between the US and the PRC intensifying further. Specifically, it assumes that both countries impose blanket tariffs of $25 \%$ on all merchandise imports from the other country. The third scenario ('worse-case scenario') includes measures under the bilateral escalation scenario and a global 
escalation of the trade conflict between the US and its trading partners, particularly in auto and auto parts and components trade. It simulates the imposition of tariffs amounting $25 \%$ on global trade of autos, parts, and components.

The immediate impact of these three scenarios, as well as the channels of trade reallocation, will take time to fully materialize. Producers and consumers will need to reallocate demand and new suppliers will need to appear to pick up the slack, some from scratch. Timing calculations for the direct effects of the tariffs based on actual and presumed dates of implementation suggest that under the current scenario, $40.4 \%$ of the estimated direct impact will be realized this year, and by 2019 , countries will bear the full brunt of the trade conflict. Under the worse-case scenario, the estimated direct impact escalates in the last quarter of 2018 , with $13.1 \%$ of the direct impact realized in 2018 . This rises exponentially to $90.8 \%$ in 2019 , assuming the tariffs on autos and retaliation take place in February 2019, when the US Department of Commerce findings are due. Direct impact will approach full effect in 2020 (99.6\%) and would be complete in 2021 (100\%) (Table 1).

\section{Table 1: Timing Calculations for Direct Effects Based on Tariffs' Dates of Effectivity}

(\%)

\begin{tabular}{lcccc}
\hline Scenario & 2018 & 2019 & 2020 & 2021 \\
\hline Current scenario & 40.4 & 100.0 & 100.0 & 100.0 \\
Worse-case scenario & 13.1 & 90.8 & 99.6 & 100.0 \\
\hline
\end{tabular}

Source: Authors' calculations.

\section{Data and Scenario Modeling}

The ADB Multiregional Input-Output Table (ADB MRIOT) for the year 2017 is used to quantify the impact of changes in tariffs working through local and production chains. It documents trade and production links between economies and industries for 35 sectors in 62 economies, including 24 in developing Asia, which together comprise $96 \%$ of the region's GDP, ${ }^{3}$ plus an economy called "rest of the world."

Using this comprehensive dataset offers two key advantages. First, it allows for the calculation of impact not just on broad regions, as is often the case with alternative models, but on individual economies and even on individual sectors within economies. Second, it enables the treatment of economies not as separate entities, but as interconnected players in a complex web of production networks. Because it shows a very detailed snapshot of the global economy at a given point in time, analyses using MRIOT have been particularly useful in understanding the structure and evolution of global value chains (see, for example, Timmer et al. 2014 and Wang, Wei, and Zhu 2018).

The direct impact of the trade conflict is first quantified at the product level. The authors gather published lists of tariff-affected commodities (including magnitudes of tariffs imposed) for all

3 The 24 economies in developing Asia (excluding Japan) individually included in the latest version of the ADB MRIOTs are: Brunei Darussalam; Cambodia; Fiji; Hong Kong, China; India; Indonesia; Kazakhstan; the Kyrgyz Republic; the Lao People's Democratic Republic; Malaysia; Maldives; Mongolia; Nepal; Pakistan; the People's Republic of China; the Philippines; the Republic of Korea; Singapore; Sri Lanka; Taipei,China; Thailand; and Viet Nam. Those not listed are part of the rest of the world. 
countries involved in the trade conflict as of end-September 2018. We match these commodities with detailed trade data from BACl and the United States Census Bureau (2017) using a 6- to 10-digit Harmonized System classification. At this level, the implied reduction in nominal import values from tariff-affected trading partners are computed using import demand elasticities.

While this paper has significant granularity of the goods impacted (at the 6-digit level of the Harmonized System classification), an issue endemic in the trade literature of aggregation arises. When aggregating from the detailed product level to the 35-sector, country-product level, the paper may be missing some substitution occurring across products within the directly affected sector-which would bias the results upward by showing a larger impact (less substitution) than what in reality occurs. Some of this is captured by the import elasticity of demand, or some of it may manifest in specific markets adjusting to the tariffs at different speeds. ${ }^{4}$ Nevertheless, the results presented here focus on the short to medium terms, where import demand elasticities are lower than in the long term: initially producers have much less time to substitute and will tend to pass on the higher tariff-induced costs through the value chain, eventually to final prices.

In order to partially address these issues, two important adjustments are allowed to account for differences in product substitutability across countries. These are adjustment using product market share, and adjustment using the product complexity index of Hidalgo and Hausmann (2009) (See Box below). The first adjustment tries to capture relative dominance or market share: if the export item from the country subject to the tariff comprises a large share of the importing country's demand for that item, the importing country cannot easily substitute away from that product. Specifically, for any given product, it is assumed that dominant exporters face a less elastic demand curve. The second adjustment assumes that product substitutability declines as product complexity rises. Simple products behave more like commodities, but if a product is very complex and difficult to produce it will be harder for the importing country to find a suitable alternative substitute, and the product will face a less elastic demand curve.

The process outlined above is performed through several steps. The scenarios are studied repeating the same process under a set of hypothetical assumptions about how the trade conflict is likely to cascade in the future. The model has been constructed to easily allow for the construction of new scenarios (including the retaliation or initiation of trade measures from other countries except the US and the PRC), as well as changes in the assumptions about the speed of adjustment for various sectors. At the product level, two rounds of impact were considered. In the first round of calculations with no trade redirection, imports from tariff-affected countries are reduced due to the tariff hikes. In the second round of impact which incorporates trade redirection, the shortfall in imports from the first round is compensated by other foreign and/or domestic suppliers, following Feenstra and Sasahara (2017)'s approach, where trade is redirected toward other producers in proportion to their current shares in the global market. This paper assumes that only half of tariff-affected trade is redirected; should actual trade redirection be greater or smaller than this, so will potential positive spillovers into other suppliers.

4 For example, soybean oil imports from the US targeted by the PRC can be substituted by soybean oil from Argentina, or for some uses, palm oil from Malaysia. Global prices of all vegetable oils will tend to adjust much faster, so elasticities are smaller (see Reimer, Zheng, and Gehlhar 2013). This is already reflected in a much larger value of the soybean oil import demand elasticity. 


\section{Factor Adjustments Made to Generate Product-Level Elasticities}

\section{Adjustment Using Market Shares}

Market shares by product reflect the relative dominance of exporters to the product imports of an importing country. Recent trade literature makes use of market shares as weights to derive an average import demand elasticity for a given set of products (Felettigh and Federico 2010, Imbs and Mejean 2017). In contrast, this study utilizes market shares to generate elasticity measures that are heterogeneous at the product level.

Given import demand elasticities $\eta_{k}$ that vary at the country level, say from Tokarick (2010), or simply are unit-elastic across all countries, the price elasticity of the demand of country $k$ for product $p$ from the exporting country $m, n_{k m}{ }^{p}$, is constructed as follows:

$$
n_{k m}{ }^{p}=\eta_{i} * \frac{\ln \left(\text { share }_{k m}^{p}\right)}{\left|\ln \left(1 / N_{k m}^{p}\right)\right|}
$$

where $N_{k m}^{p}$ is the number of countries $m$ exporting product $p$ to country $i$. All tariff-affected countries are treated as one. This formula implies that ${n_{k m}}^{p} \rightarrow 0$ as Share $k_{k m}^{p} \rightarrow 1$. Furthermore, $n_{k m}{ }^{p} \rightarrow-\infty$ as Share $_{k m}^{p} \rightarrow 0$. As the product market share of the exporting country increases, this elasticity tends to zero.

\section{Adjustment Using the Product Complexity Index}

Empirical evidence suggests that product sophistication impacts countries' sensitivities to changes in prices of imported goods (Arbatli and Hong 2016). Thus, product sophistication is factored into the calibration of elasticities by constructing a factor adjustment based on the product complexity index developed by Hidalgo and Hausmann (2009).

The most recent product complexity dataset (2016) is used to construct this factor adjustment. The assignment of elasticities to products satisfies the following conditions: (a) products that have a high product complexity index $\left(P C I_{p}\right)$ are assigned less elastic import demand elasticities, while (b) products that have low $\mathrm{PCI}_{p}$ (hence, less sophisticated) are assigned more elastic import demand elasticities. It is assumed that more complex and/or sophisticated products are not easily substitutable in global trade, while the opposite is true for less complex products. So, given initial country-level import demand elasticities $n_{k}$, the price elasticity of demand of country $k$ for product $p$ from the exporting country $m, n_{k m}{ }^{p}$ is constructed in the following manner.

$$
n_{k m}{ }^{p}=n_{i} * \frac{P C I_{p}-\max \left(\operatorname{range}\left(P C I_{p}\right)\right)}{P C I_{p}-\min \left(\operatorname{range}\left(P C I_{p}\right)\right)+0.001}
$$

The baseline results are based on short-run, country-level import demand elasticities sourced from Tokarick (2010) without any factor adjustment, but the implications of relaxing this assumption are examined in the sensitivity analysis in section $\mathrm{V}$ below.

Sources: Arbatli, Elif, and Gee Hee Hong. 2016. "Singapore’s Export Elasticities: A Disaggregated Look into the Role of Global Value Chainsand Economic Complexity." IMF Working Paper No. 16/52; Felettigh, Alberto, and Stefano Federico. 2010. "Measuring the Price Elasticity of Import Demand in the Destination Markets of Italian Export." Bank of Italy Economic Working Paper No. 776; Hidalgo, César, and Ricardo Hausmann. 2009. "The Building Blocks of Economic Complexity." Proceedings of the National Academy of Sciences 106 (28): 10570-75; Imbs, Jean, and Isabelle Mejean. 2017. "Trade Elasticities." Review of International Economics 25 (2): 383-402; Tokarick, Stephen. 2010. "A Method for Calculating Export Supply and Import Demand Elasticities." IMF Working Paper No. 10/180. 
Changes in imports at the product level are aggregated by industry and type of use categories that are consistent with international statistical classifications. These changes are applied to the benchmark 2017 ADB MRIOT, which reflect modeled scenario assumptions. The benchmark and modeled MRIOTs are used as inputs to the Leontief demand-pull analysis, which was utilized to estimate the direct and indirect impacts (including potential trade redirection effects) of the trade conflict.

Table 2: Description and Size of Modeled Scenarios

\begin{tabular}{|c|c|c|c|}
\hline $\begin{array}{l}\text { Scenarios Analyzed } \\
\text { (cumulative) }\end{array}$ & $\begin{array}{l}\text { United States (US) Tariff } \\
\text { Actions and Size of Impact }\end{array}$ & $\begin{array}{l}\text { Retaliatory Measures by Other } \\
\text { Countries }\end{array}$ & $\begin{array}{l}\text { Date of } \\
\text { Implementation }\end{array}$ \\
\hline \multirow[t]{5}{*}{$\begin{array}{l}\text { Current Scenario } \\
\text { (measures } \\
\text { implemented as of } \\
\text { October 2018) }\end{array}$} & $\begin{array}{l}30 \% \text { and } 20 \% \text { blanket tariffs on } \\
\text { all imports of solar panels and } \\
\text { washers worth } \$ 10.3 \text { billion ( } 0.4 \% \\
\text { of US imports) }\end{array}$ & $\begin{array}{l}\text { The People's Republic of China (PRC) } \\
\text { imposes } 15 \% \text { and } 25 \% \text { tariffs on } \$ 3 \\
\text { billion worth of US goods } 2.3 \% \text { of US } \\
\text { exports to the PRC) }\end{array}$ & First quarter 2018 \\
\hline & $\begin{array}{l}25 \% \text { and } 10 \% \text { blanket tariffs on all } \\
\text { imports of steel and aluminum } \\
\text { products worth } \$ 48 \text { billion ( } 2 \% \text { of } \\
\text { US imports) }\end{array}$ & $\begin{array}{l}\$ 35.8 \text { billion in retaliatory tariffs against } \\
\text { US steel and aluminum tariffs by } \\
\text { Canada ( } \$ 16.6 \text { billion), India ( } \$ 10.6 \\
\text { billion), the European Union (EU) ( } \$ 3.2 \\
\text { billion), Mexico ( } \$ 3 \text { billion), Turkey } \\
\text { ( } \$ 2.31 \text { billion), and the Russian } \\
\text { Federation ( } \$ 87.6 \text { million). Brazil and } \\
\text { the Republic of Korea receive quota } \\
\text { and are exempt from tariffs. }\end{array}$ & March-April, 2018 \\
\hline & $\begin{array}{l}25 \% \text { on } \$ 34 \text { billion worth of PRC } \\
\text { goods ( } 7 \% \text { of PRC exports to the US) }\end{array}$ & $\begin{array}{l}\text { PRC } 25 \% \text { on } \$ 34 \text { billion worth of US } \\
\text { goods ( } 26 \% \text { of US exports to the PRC) }\end{array}$ & 6 July 2018 \\
\hline & $\begin{array}{l}25 \% \text { on } \$ 16 \text { billion worth of PRC } \\
\text { goods ( } 3 \% \text { of PRC exports to the US) }\end{array}$ & $\begin{array}{l}\text { PRC } 25 \% \text { on } \$ 16 \text { billion worth of US } \\
\text { goods ( } 12.3 \% \text { of US exports to the PRC) }\end{array}$ & 23 August 2018 \\
\hline & $\begin{array}{l}10 \% \text { on } \$ 200 \text { billion worth of } \\
\text { PRC goods raised to } 25 \% \text { on } 2019 \\
\text { ( } 40 \% \text { of PRC exports to the US) }\end{array}$ & $\begin{array}{l}\text { PRC } 5 \%, 10 \%, 20 \% \text {, and } 25 \% \text { on } \$ 60 \\
\text { billion worth of US goods ( } 46 \% \text { of US } \\
\text { exports to the PRC) }\end{array}$ & $\begin{array}{l}\text { Begins } 24 \\
\text { September and } \\
\text { escalates } \\
1 \text { January } 2019\end{array}$ \\
\hline $\begin{array}{l}\text { Bilateral Escalation } \\
\text { Scenario (add } 25 \% \\
\text { tariffs on all bilateral } \\
\text { US-PRC imports) }\end{array}$ & $\begin{array}{l}\text { US blanket tariffs of } 25 \% \text { on } \\
100 \% \text { of PRC exports to the US } \\
\text { worth } \$ 505.5 \text { billion (an } \\
\text { additional } \$ 267 \text { billion from } \\
\text { previous scenario) }\end{array}$ & $\begin{array}{l}\text { PRC blanket tariffs of } 25 \% \text { on } 100 \% \text { of } \\
\text { US exports to the PRC worth } \$ 130 \\
\text { billion (an additional } \$ 17 \text { billion added } \\
\text { from previous scenario) }\end{array}$ & $\begin{array}{l}\text { Model assumes } \\
\text { first quarter } 2019\end{array}$ \\
\hline $\begin{array}{l}\text { Worse-Case } \\
\text { Scenario (add } 25 \% \\
\text { tariff on all autos and } \\
\text { parts + retaliation) }\end{array}$ & $\begin{array}{l}\text { US blanket tariffs of } 25 \% \text { on all } \\
\text { imports of autos worth } \$ 350 \\
\text { billion-including sports utility } \\
\text { vehicles, vans, and light trucks, } \\
\text { and auto parts worth about } 14.5 \% \\
\text { of US imports equivalent to } \\
0.44 \% \text { of global gross domestic } \\
\text { product }\end{array}$ & $\begin{array}{l}\text { Retaliatory measures by other } \\
\text { countries on all their auto and auto } \\
\text { parts imports from the US worth } \$ 130 \\
\text { billion ( } 6.8 \% \text { of total US merchandise } \\
\text { exports). US auto import partners } \\
\text { include: Mexico ( } \$ 106.1 \text { billion), } \\
\text { Canada ( } \$ 61.9 \text { billion), Japan ( } \$ 55.2 \\
\text { billion), the United Kingdom ( } \$ 30.7 \\
\text { billion), the Republic of Korea ( } \$ 22.2 \\
\text { billion), the PRC ( } \$ 20.3 \text { billion), and } \\
\text { Germany ( } \$ 10.6 \text { billion) }\end{array}$ & $\begin{array}{l}\text { Model assumes } \\
\text { first quarter } 2019\end{array}$ \\
\hline
\end{tabular}


The modeled scenarios and countries involved are described in Table 2 and the detailed list of goods affected in Appendix Table A1. Our results yield estimates of changes in exports, GDP and employment for each of the $35 \times 63$ country-sector pairs of the latest available full year (2017), with impacts occurring through three different but interrelated channels: the direct effect, indirect effect, and trade redirection. ${ }^{5}$

\section{Input-Output Analysis}

Data on the flow of economic transactions across country-industries worldwide is summarized in multiregional input-output tables. In the analysis presented here, output in each country-industry pair is produced using domestic production factors (capital and labor) and intermediate inputs, which are sourced either domestically or from foreign suppliers. This may be used to satisfy final demand or be used as an intermediate input to production (at home or abroad) (Los, Timmer, and de Vries 2015). Assuming there are $m$ countries and $n$ sectors in each country, the $m n$ country-industry pairs in the global economy constitute the most detailed units of observation in this analysis.

Tariff change is modeled as a shock that alters the overall level and distribution of intermediate and final demand across economies worldwide. Suppose 0 is the superscript for the initial benchmark state and 1 is for the modeled scenario, the fundamental input-output identity by Leontief (1936) implies that the change in gross output $\Delta \mathbf{y}$ can be expressed in matrix form as:

$$
\Delta y=\mathbf{y}^{1}-\mathbf{y}^{0}=\mathbf{B}^{1} \mathbf{f}^{1}-\mathbf{B}^{0} \mathbf{f}^{0}
$$

Here, $\mathbf{y}$ refers to the $m n$ vectors of output and $\mathbf{f}$ for the final demand, while $\mathbf{B}$, a matrix of size $m n-$ by $-m n$, is the so-called global Leontief inverse. It indicates the output of each country-industry $i$ that is required per unit of final demand for the products delivered by country-industry $j$.

The methodology described above is standard and may be extended to derive estimates of employment and value-added changes attributable to shocks. For instance, let $\mathbf{e}$ be the $m n$ vectors of employment and $\mathbf{v}$ for value added by country-industry pair. Then, the total labor demand generated across country-industries may be expressed $\mathbf{e}=\hat{\mathbf{l}} \mathbf{B f}$ and that for value added by $\mathbf{v}=\widehat{\mathbf{v B f}}{ }^{6}$ Here, $\mathbf{l}$ and $\boldsymbol{v}$ are the $m n$ vectors of employment per unit of output and value added per unit of output. Thus, change in employment and change in value added can be modeled using multiregional input-output analysis as:

$$
\begin{aligned}
& \Delta \mathbf{e}=\mathbf{e}^{\mathbf{1}}-\mathbf{e}^{\mathbf{0}}=\hat{\mathbf{l}} \mathbf{B}^{\mathbf{1}} \mathbf{f}^{\mathbf{1}}-\hat{\mathbf{l}} \mathbf{B}^{\mathbf{0}} \mathbf{f}^{\mathbf{0}} \\
& \text { and } \\
& \Delta \mathbf{v}=\mathbf{v}^{\mathbf{1}}-\mathbf{v}^{\mathbf{0}}=\widehat{v} \mathbf{B}^{1} \mathbf{f}^{\mathbf{1}}-\widehat{v} \mathbf{B}^{0} \mathbf{f}^{\mathbf{0}}
\end{aligned}
$$

5 Here GDP refers to gross domestic product at basic prices or, analogously termed gross value added. In contrast, GDP in official statistics is valued at market prices. That is, it is the sum of gross value added of all resident producer units plus taxes on products, less subsidies on products. Meanwhile, gross value added is the difference between output and intermediate consumption.

6 A hat (e.g., Î) indicates a diagonal matrix, with the elements of the vector I on the diagonal. 


\section{E. Comparison with Other Analyses of the Trade Conflict}

Several other analyses of the effects of the trade conflict have been published. Their results are often not directly comparable because of differences in scenario assumptions, or noncomparability of regions or time periods. A few of these are discussed below, and a detailed summary of studies can be found in Appendix Table A2.

(i) Li, He, and Lin (2018) use a multicountry general equilibrium model to discuss the possible impacts of an escalated bilateral trade conflict between the PRC and the US by simulating various tariff rates on PRC and US imports. The negative effects manifest more prominently in the GDP of the PRC, which is seen to decline by 1.15 percentage points when tariffs are at 30\%. On the other hand, the US gains by a small amount: $0.04 \%$ of GDP. Although the trade conflict hurts the PRC more than any other economy, they find the effects are still manageable (although the impact for both countries is more severe the higher the tariff rate). One of the limiting factors in this study is the lack of countrylevel demand elasticities, unlike our approach.

(ii) Bollen and Rojas-Romagosa (2018), under the purview of the Netherlands Bureau for Economic Policy Analysis (CPB), used WorldScan-a 30-country, 29-product recursive dynamic computable general equilibrium (CGE) model based on the latest Global Trade Analysis Project version 9 database with base year 2011. To compensate for the lack of granularity inherent in the model, a sectoral trade-weighted average tariff is estimated to aptly account for the relative importance of individual product tariffs within the sector, based on current trade values. Results show that the economic effects of current measures are limited, but some specifically targeted sectors in the PRC and the US suffer more. Over time, amid more tariffs, the PRC's economic loss is equivalent to $1.3 \%$ of GDP, whereas the decline in the US is limited to $0.3 \%$ of GDP. Other economies benefit via the trade diversion channel, but this quickly fades once the US levies tariffs on autos and other products.

(iii) In the October 2018 World Economic Outlook report, the IMF uses a multiregional dynamic stochastic general equilibrium model known as the Global Integrated Monetary and Fiscal model, which has overlapping generations of consumers, thus providing rich dynamics. The model has well-specified monetary and fiscal policy functions, and thus is appropriate for analyzing policy shocks and incorporating endogenous policy responses. The major drawbacks are that it cannot capture some of the sectoral distortions that the proposed trade restrictions are likely to generate, and does not account for spillovers via global production networks. However, IMF (2018b) adds a Ricardian trade model extension which accounts for sectoral redistribution for four countries in developing Asia: India, Indonesia, the PRC, and the Republic of Korea. The IMF analyzes five different scenarios that include: all measures that have already been implemented, plus retaliation from all US trading partners with tariffs on an equivalent amount of US exports (scenario 1); a heightened US-PRC bilateral trade war with tariffs rising to $25 \%$ on remaining unaffected goods (scenario 2); auto sector trade conflict (scenario 3); investmentreducing "confidence shock" (scenario 4); and "market reactions" from tightening financial conditions (scenario 5). The three scenarios used in this working paper correspond most closely to the IMF's scenarios 1, 2, and 3. The cumulative negative effect is seen to peak in the second year, or in 2020, where global GDP is seen to decline by 
$0.8 \%$ relative to before trade tensions improving to $0.4 \%$ over the medium term. This is mostly attributable to confidence effects and market reactions, while the effects of the tariffs themselves are relatively small. Over the long term, where adjustments have taken place, output in the US is affected the most, with almost $1 \%$ below a no-trade-war scenario, and output in the PRC declines by $0.5 \%$ below the baseline.

(iv) The European Central Bank Economic Bulletin (Issue 6/2018) prepared by Dizioli and van Roye, employed a multicountry, multisector model that uses both the ECB's global model and the IMF's Global Integrated Monetary and Fiscal model. The primary assumption is that the duration of the trade conflict is expected to last for only 2 years, which is short in comparison with the IMF model that runs until 2022 and the CPB model which is until 2030. The current scenario resembles an earlier landscape of the trade conflict, in which the US imposed tariffs on steel (25\%), aluminum (10\%), and $\$ 50$ billion of US-PRC bilateral trade (25\%), while the bilateral escalation scenario is depicted as blanket $10 \%$ tariffs on US imports with retaliation from trading partners. The ECB finds that the current scenario would have a marginal effect on global GDP, but the US and the PRC are individually badly affected: real GDP in the US is expected to weaken by $1.5 \%$ as lower exports negate the gains in domestic shares of US firms. It is slightly positive for the PRC, but gains diminish over the 2-year span. As with the IMF model, a fall in confidence has significant adverse effects on global GDP.

(v) Two CGE analyses using the Global Trade Analysis Project are by Zhai and Zhuang (2017) and Kutlina-Dimitrova and Lakatos (2017) also show similar results. In a scenario in which the PRC and the US impose a 40\% tariff on all their imports using 2011 data, Zhai and Zhuang (2017) find that total trade falls by $0.22 \%$ of global GDP.

\section{RESULTS}

This section summarizes the main results, showing the impact of each scenario across different countries and regions, and discusses in detail the potential global and economywide impact on GDP, exports, employment, and current account balances.

\section{A. Effects on Gross Domestic Product}

\section{Overall Impact}

Under the current scenario, both the PRC and the US are negatively affected, with a larger impact on the PRC (Figure 3 top panels, blue bars). The trade measures already implemented would lower GDP in the PRC by $0.5 \%$ relative to what it would have been in the absence of any trade conflict. The impact on the US is substantially smaller, subtracting $0.1 \%$ of GDP. For both economies, most of the negative impact is felt through direct and indirect channels. The difference in the size of the effects across the two economies should not be surprising. As Figure 1 showed, the tariffs imposed by the US on the PRC are an order of magnitude larger than those imposed by the PRC on the US, and the PRC is more dependent on US demand for its goods than the US is on PRC demand.

Should the bilateral trade conflict escalate to cover all goods traded between the two countries, the effects on GDP in the two countries would be significantly larger, with the PRC again 
being hit the most (Figure 3 top panels, first yellow bars). GDP in the PRC would decline by just over $1 \%$, with most of the effects again coming in as direct effects of the tariffs and indirect effects delivered through domestic production linkages. The US would see its GDP fall by $0.2 \%$ relative to a baseline of no-conflict.

Under the worse-case scenario where a global trade conflict in autos and auto parts materializes, global effects are somewhat more significant, with global GDP declining by $0.25 \%$. The trade conflict in autos and auto parts has only a marginal incremental effect on PRC's GDP, and in the US trade redirection toward domestic producers helps ameliorate the effects of an auto trade war. Instead, much of the additional negative impact of a trade conflict in autos and auto parts is borne by Europe and Japan.

The rest of developing Asia may actually benefit through trade redirection. For the rest of developing Asia outside the PRC, the impact of the trade conflict through the direct effects of tariffs and indirect effects conveyed via production links are negative but relatively small: $-0.06 \%$ in the current scenario and $-0.24 \%$ in the worse-case scenario (Figure 3 bottom right panel). Allowing for trade redirection, the net effect on the rest of developing Asia turns mildly positive, at $0.07 \%$ under the current scenario and $0.16 \%$ under the worse-case scenario. The potential gain from trade redirection is $0.13 \%$ of GDP under the current scenario and $0.4 \%$ with the worse-case scenario. The economies in the region that stand to benefit the most are, in descending order, Viet Nam $(+2.14 \%)$; Malaysia $(+0.46 \%)$; Taipei,China ( $+0.42 \%)$; and Thailand $(+0.22 \%)$ because they produce and export goods that compete with products from economies affected by the tariffs. Appendix Table A3 presents a detailed summary of the impact on GDP, employment, and exports of 24 developing Asian economies under each scenario. ${ }^{7}$

7 More detailed country and sectoral results are available at https://data.adb.org/dataset/trade-conflict-impact. 
Figure 3: Impact of the Trade Conflict on Gross Domestic Product, by Scenario
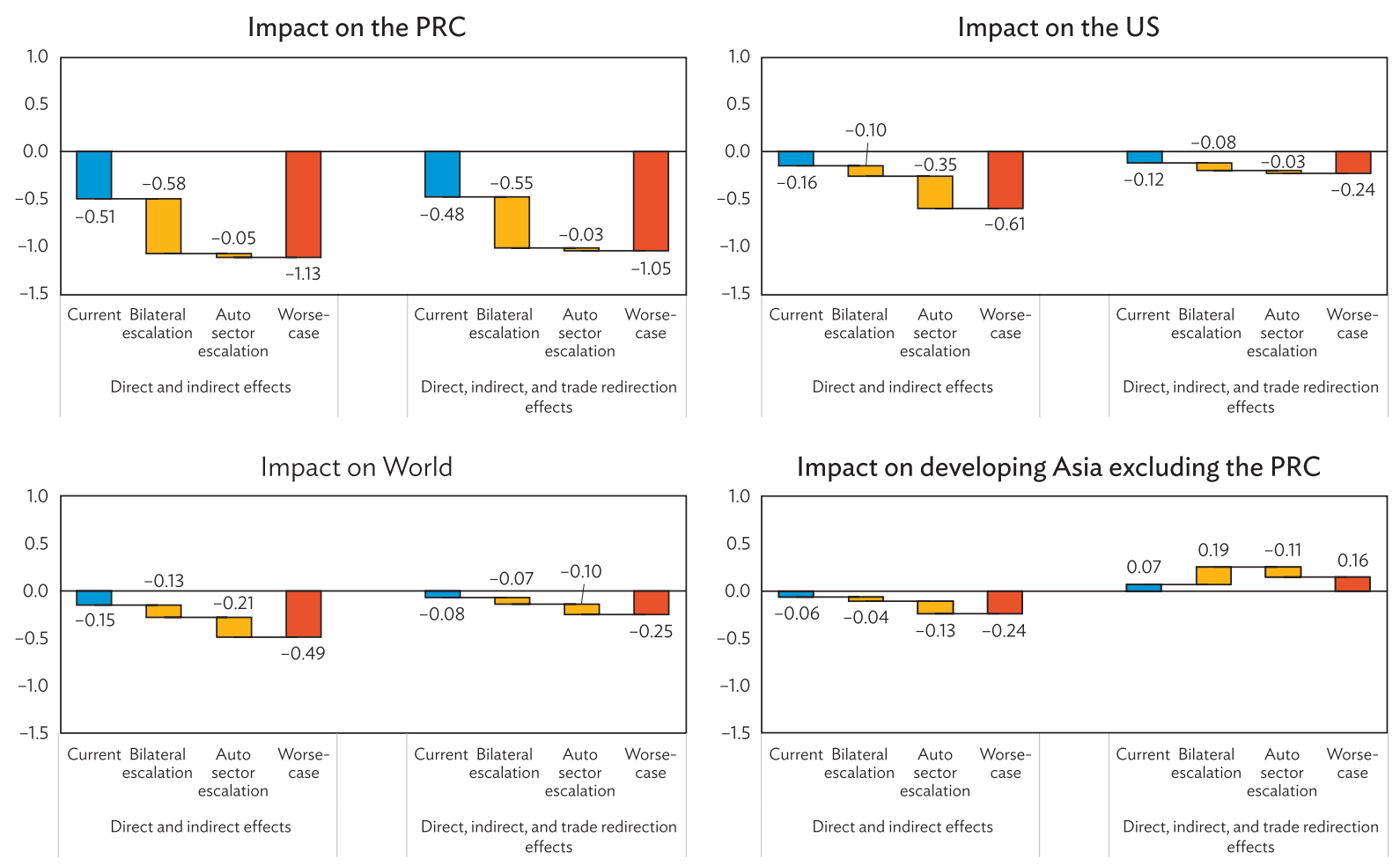

GDP = gross domestic product, PRC = People's Republic of China, US = United States.

Note: The blue bars represent the estimated GDP impact under the current scenario. The first yellow bar represents the incremental impact brought about by the US-PRC trade threats (25\% on all bilateral exports) and the second bar is the auto sector (tariffs on all auto and auto parts traded globally) escalation. The red bars represent the sum of all the impacts under the worse-case scenario.

Source: Authors' calculations.

\section{Sectoral Impact}

From a sector perspective, the negative impact of the trade conflict on the PRC cuts across many sectors, while the gains in the rest of developing Asia are concentrated in only a few (Figure 4). For example, under the worse-case scenario, the PRC electronics industry is the hardest hit by $0.15 \%$ of GDP. Other affected sectors in order of impact include wholesale trade, mining and quarrying, agriculture, textiles and garments, financial services, manufacture of metals, chemicals, and industrialpurpose machinery. The presence of wholesale trade and financial services in the list illustrates the significant role that production linkages play in transmitting the impact of the trade conflict throughout the economy. For the rest of developing Asia, the potential benefit from trade redirection is concentrated in sectors where the region competes with the PRC. Foremost among them is electronics, which is boosted substantially in Southeast Asia (ASEAN-5 countries: Indonesia, Malaysia, the Philippines, Thailand, and Viet Nam) and the newly-industrialized economies (NIEs). Textiles and garments sector also benefits in ASEAN-5 economies, and metals in the NIEs will gain because the 
Republic of Korea is one of the few countries exempted from the US tariffs on steel. ${ }^{8}$ In contrast, the gains for other economies in developing Asia outside the ASEAN-5 and the NIEs are primarily in textiles, agriculture, and wholesale trade.

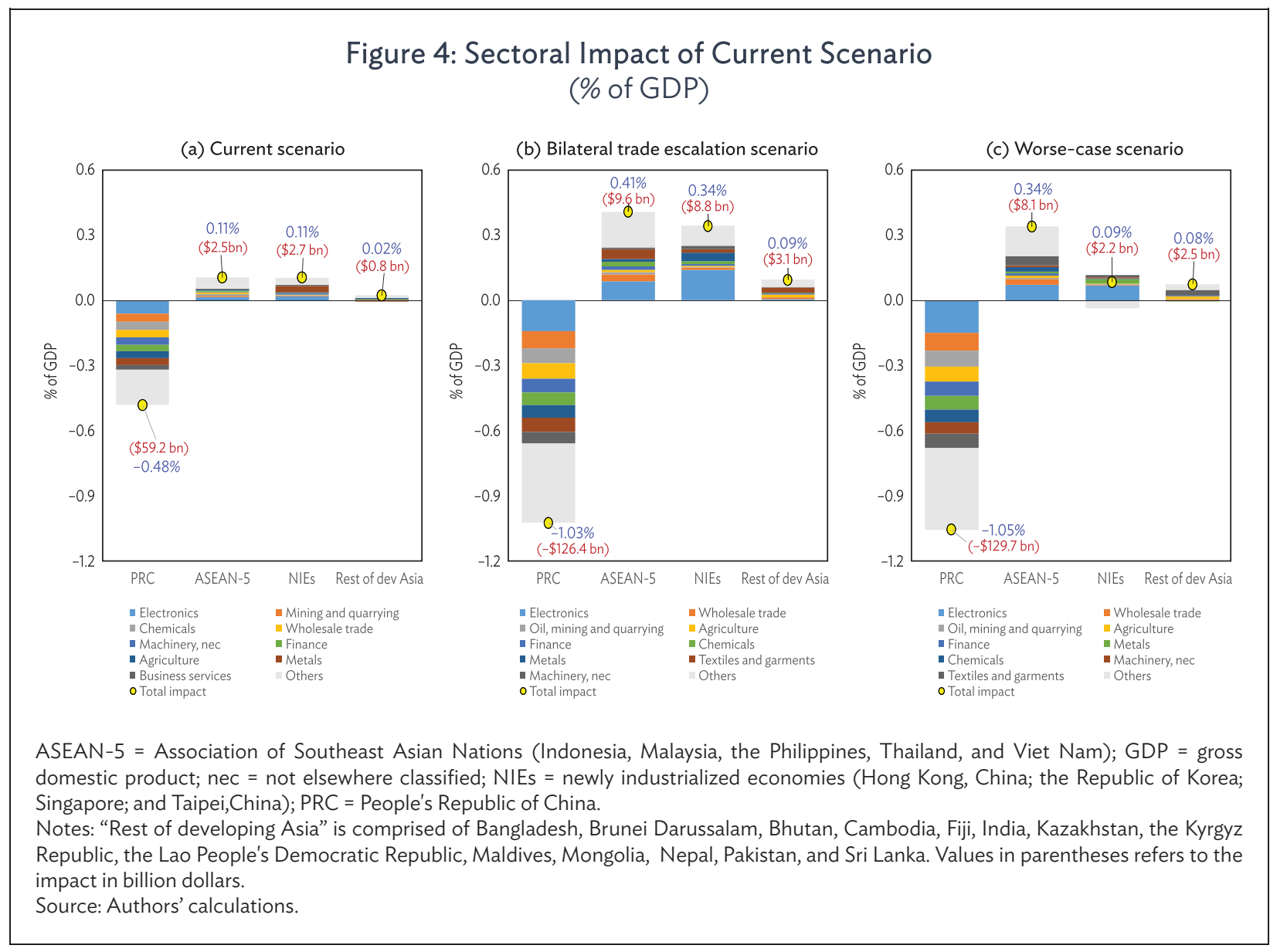

\section{B. Effects on Exports}

\section{Overall Impact}

Under the current scenario, the net decline in global trade, measured by exports, is minor, at $0.4 \%$. Not surprisingly, the two protagonists of the trade conflict-the US and the PRC-are the biggest losers (Figure 5A). The decline in exports is largest in the PRC at 3.6\%, while the US endures a weaker decline of $1.9 \%$. This is explained by the PRC's greater dependence on US markets as an export destination visà-vis the US's lower reliance on PRC markets. The increase in other economies' exports resulting from redirection of trade is not significant.

8 While imports of steel from certain trade partners (namely, Argentina, Brazil, and the Republic of Korea) were subject to quota restrictions, such trade transactions were treated in the model as 'exempted' from punitive duty rates. This implies that these trade partners may still benefit, albeit limitedly, from trade redirection since no additional tariffs were imposed on steel imports, and prices were assumed to remain intact. Thus, the results may overestimate the gains in trade redistribution of exempted countries for steel and steel products. However, this limitation in data modeling may be slightly tolerated in light of new administrative measures granting targeted relief from steel quotas. 
Figure 5: Impact on Exports, by Country

(a) Current scenario

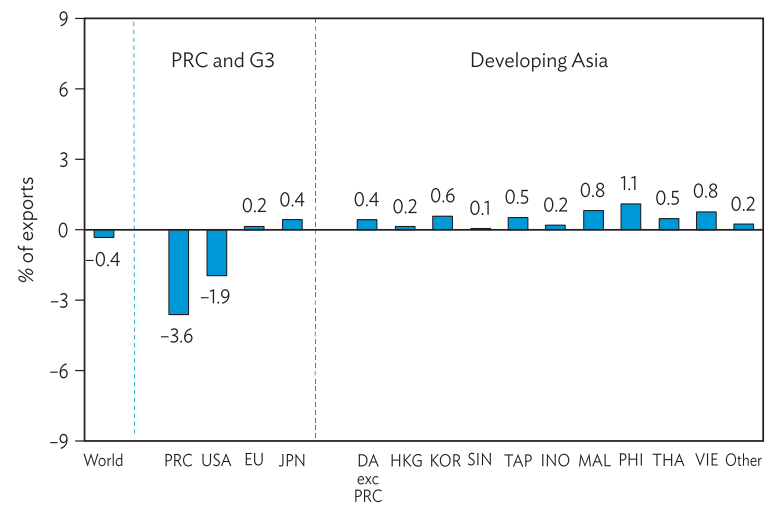

(b) Bilateral escalation scenario

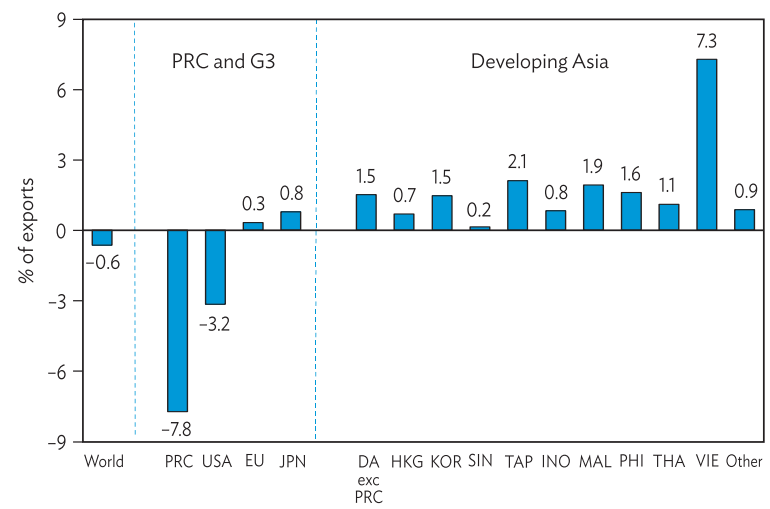

(c) Worse-case scenario

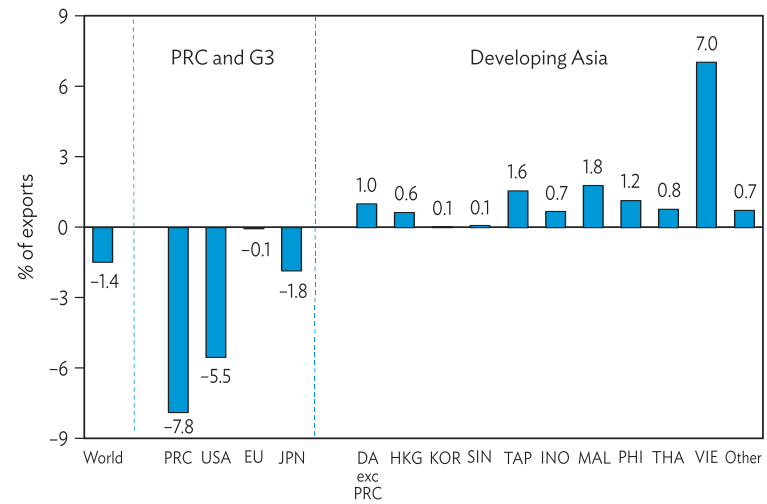

$\mathrm{DA}=$ developing Asia; $\mathrm{EU}=$ European Union; $\mathrm{HKG}=$ Hong Kong, China; = INO = Indonesia; JPN = Japan; KOR = Republic of Korea; MAL = Malaysia; PHI = Philippines; PRC = People's Republic of China; SIN = Singapore; TAP = Taipei, China; THA = Thailand; US = United States; VIE = Viet Nam.

Notes: G3 includes the euro area, Japan, and the United States. "Other" here refers to Bangladesh, Brunei Darussalam, Bhutan, Cambodia, Fiji, India, Kazakhstan, the Kyrgyz Republic, the Lao People's Democratic Republic, Maldives, Mongolia, Nepal, Pakistan, and Sri Lanka.

Source: Authors' calculations.

The global impact of the bilateral escalation scenario is marginal relative to the current scenario (Figure 5B). The imposition of blanket tariffs on bilateral exports to the PRC and the US, however, would hit the PRC the hardest with an additional $4.2 \%$ decline in total exports. In contrast, the EU and Japan will see a slight increase in exports of about $0.3 \%-0.8 \%$. Economies in developing Asia would see exports rise reflecting trade redirection in sectors such as electrical and optical equipment, textiles, and chemicals. Exports from Viet Nam would rise by $7.3 \%$, and other economies such as Taipei,China (+2.1\%) and Malaysia (+1.9\%) would see smaller but still considerable export gains.

Escalation of trade conflict to the Worse-case scenario, including tariffs on autos and auto parts, can bring down global trade by $1.4 \%$. (Figure $5 \mathrm{C}$ ). The US would experience a larger decline in exports of $5.5 \%$, while gains in exports for Japan $(-1.8 \%)$ and the EU $(-0.1 \%)$ are negated. Trade 
redirection benefits in developing Asia would see a slight decline owing to lower US demand for auto and auto parts.

\section{Sectoral Impact}

Under the worse-case scenario, the impact of trade redirection effects in two of the most important sectors for the region-electrical and optical equipment ('electronics') and textile and garments-is significant. As seen in Figure 4C, ASEAN-5 is set to gain in both these sectors, the NIEs primarily in electronics, and the rest of developing Asia in textiles. On a per country basis, however, these benefits are not equally distributed, suggesting varying technological intensity and/or degree of participation in global value chains.

The NIEs and ASEAN-5 have well-established supply bases for manufacturing electrical and optical equipment and components, making them the most viable alternative for similar goods imported from the PRC. ${ }^{9}$ The current scenario does not significantly boost electronics exports in the region (Figure $6 \mathrm{~A}$ ). An escalation to the bilateral scenario entails total coverage of every electronics product that the US imports from the PRC. As a result, effects are more pronounced as demand for PRC electronics is drastically cut by an estimated $\$ 72.4$ billion, equivalent to $3.1 \%$ of total PRC exports (Figure 6B). The resulting trade redirection toward other electronic producers primarily benefits ASEAN-5 ( $\$ 9$ billion) and NIEs ( $\$ 10.2$ billion), with Viet Nam increasing total exports by $3.5 \%$ and Taipei,China by $1.2 \%$. The marginal impact on the electrical and optical equipment sector when trade conflict in autos is added in the worse-case scenario is modest with a reduction of $\$ 1$ billion in potential gains (Figure 6C).

\footnotetext{
${ }^{9}$ Total exports of these goods comprise $28 \%$ of NIEs and $16 \%$ of ASEAN-5's total exports.
} 
Figure 6: Developing Asia: Impact on Electrical and Optical Equipment Exports

(a) Current scenario

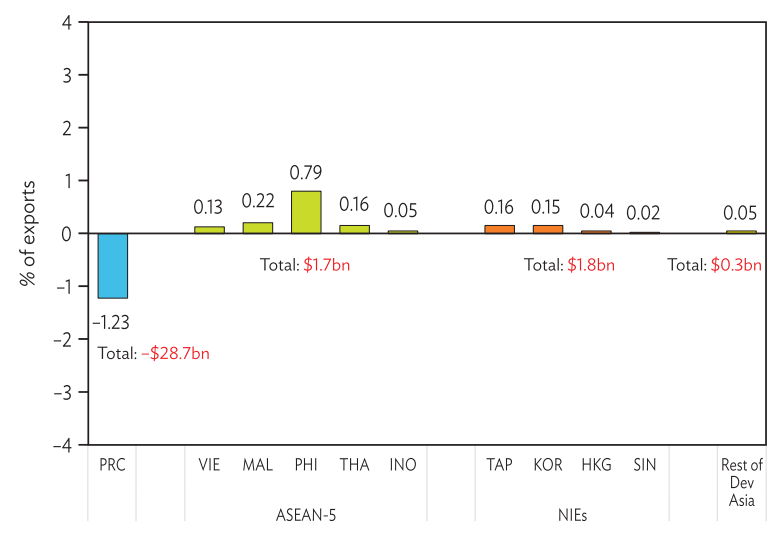

(b) Bilateral escalation scenario

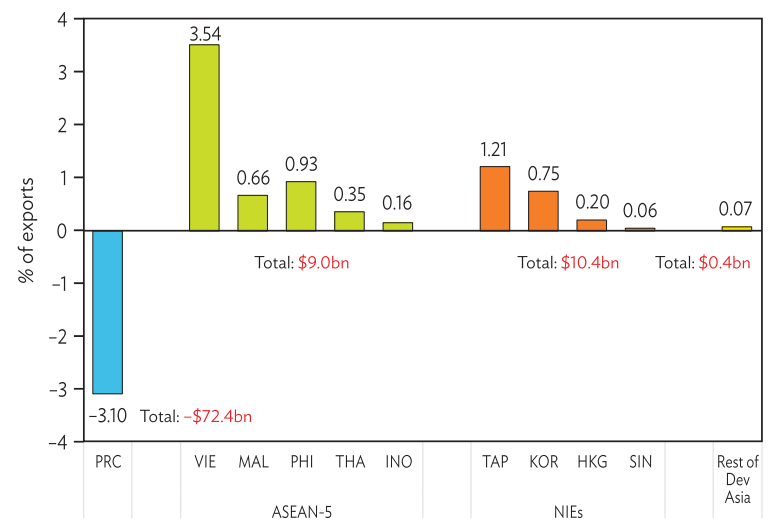

(c) Worse-case scenario

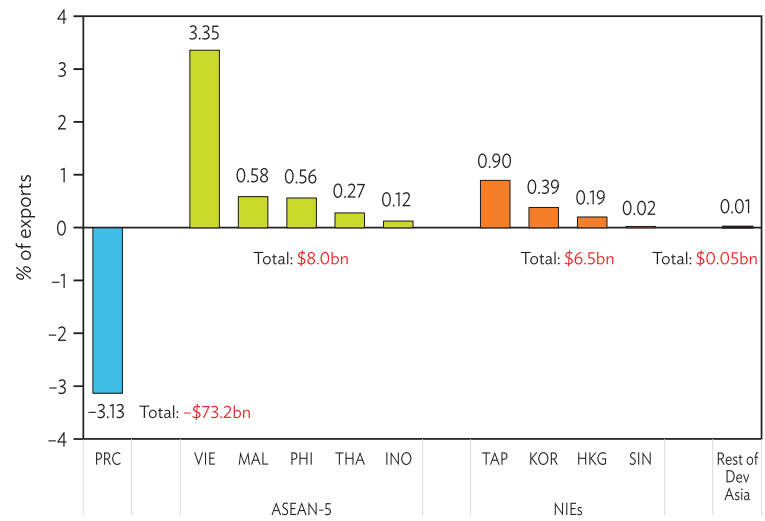

HKG = Hong Kong, China; INO = Indonesia; KOR = Republic of Korea; MAL = Malaysia; PHI = Philippines; PRC = People's Republic of China; SIN = Singapore; TAP = Taipei,China; THA = Thailand; VIE = Viet Nam.

Note: "Other" here refers to Bangladesh, Brunei Darussalam, Bhutan, Cambodia, Fiji, India, Kazakhstan, the Kyrgyz Republic, the Lao People's Democratic Republic, Maldives, Mongolia, Nepal, Pakistan, and Sri Lanka.

Source: Authors' calculations.

A number of developing Asian economies are dependent on the textile and garment sector for their external trade. This is shown in the bilateral escalation scenario (Figure 7B) wherein exports in smaller developing Asian economies such as Cambodia, Bangladesh, Sri Lanka, Pakistan would see increases in sector exports ranging from $1.3 \%$ to $3.4 \%$. The total magnitude of redirected trade is estimated to reach $\$ 2.4$ billion, which is slightly lower than that of ASEAN-5 with $\$ 2.8$ billion. 
Figure 7: Developing Asia: Impact on Textile and Garment Exports

(a) Current scenario

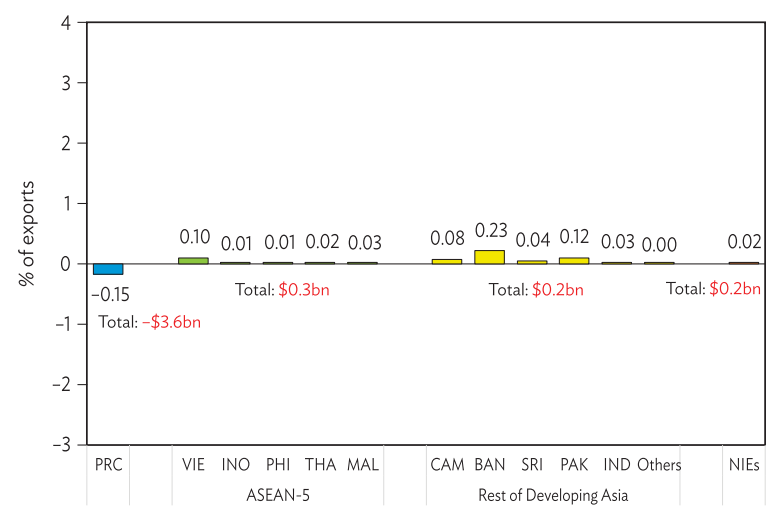

(b) Bilateral escalation scenario

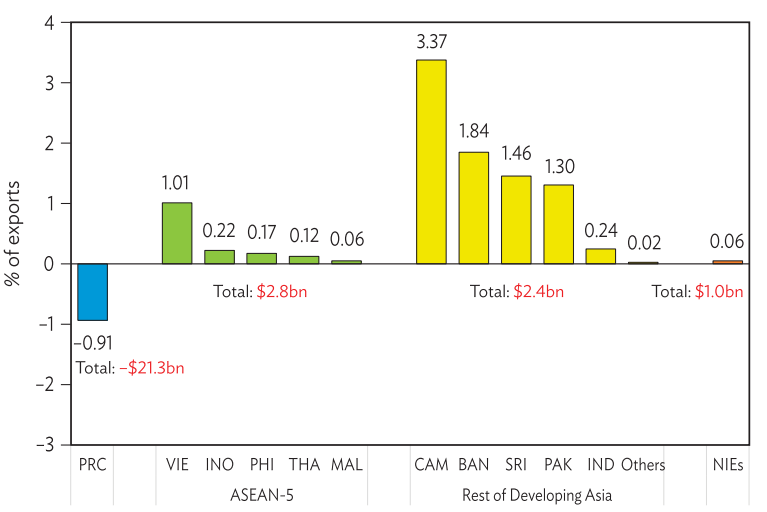

(c) Worse-case scenario

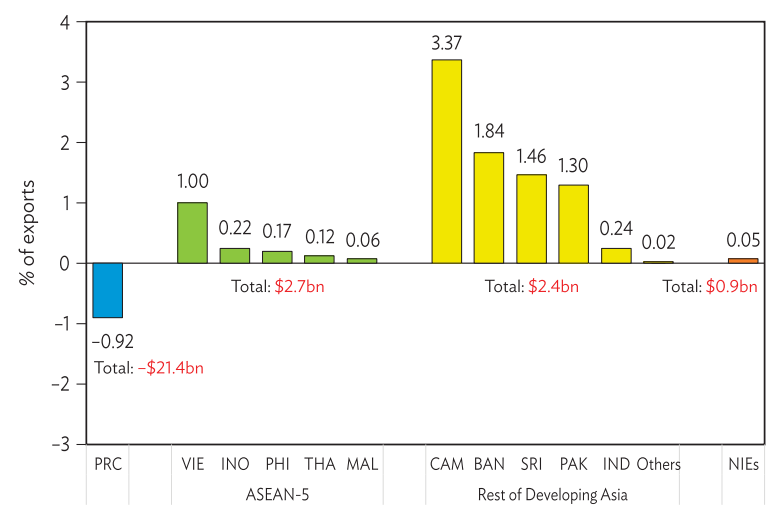

HKG = Hong Kong, China; INO = Indonesia; KOR = Republic of Korea; MAL = Malaysia; PHI = Philippines; PRC = People's Republic of China; $\mathrm{SIN}=$ Singapore; TAP = Taipei, China; THA = Thailand; VIE = Viet Nam.

Note: "Other" here refers to Bangladesh, Brunei Darussalam, Bhutan, Cambodia, Fiji, India, Kazakhstan, the Kyrgyz Republic, the Lao People's Democratic Republic, Maldives, Mongolia, Nepal, Pakistan, and Sri Lanka.

Source: Authors' calculations.

\section{Effects on Employment}

The effect on global employment under the current scenario is negative amidst weaker global GDP and lower trade. Employment outcomes vary greatly between the PRC vis-à-vis the US and other economies. The initial wave of trade measures under the current scenario could result in a loss of 3.5 million jobs in the PRC, while the US would see a loss of about 180,000 jobs. Employment effects outside these two economies are fairly insignificant, with slight gains for the rest of developing Asia (Figure 8A). Under the bilateral escalation scenario, the resulting potential employment losses in the PRC may exceed 8.5 million or $1 \%$ of total employment (Figure $8 \mathrm{~B}$ ). The worse-case scenario will negatively affect employment in developed economies such as the EU and Japan, while the US will likely experience employment declines that are a fraction (no more than one-fifth) of a percent (Figure $8 \mathrm{C}$ ).

A closer look at the five sectors that are most prominently affected for selected economies reflect their relative labor intensity (See Table 3). In the PRC, sectors such as agriculture, community, 
social and personal services, retail trade, textiles and garments, and electronics account for over $60 \%$ of the total employment loss, indicating their high labor intensity in production. In the US, where the employment drop is smaller, the business activities sector has a large labor loss despite it being a nontraded service sector, reflecting the sector's labor intensity and the importance of intersectoral linkages. Although US agricultural exports are directly impacted, only 53,000 jobs are shed reflecting the sector's high capital intensity. Employment in the transport equipment sector in the US increases slightly, unlike in other sectors, reflecting the large number of domestic auto and parts producers. In developing Asia, excluding the PRC, higher levels of trade and economic activity substantially improve employment in the sectors where the PRC sheds jobs.

\section{Figure 8: Impact on Employment, by Country}

(a) Current scenario

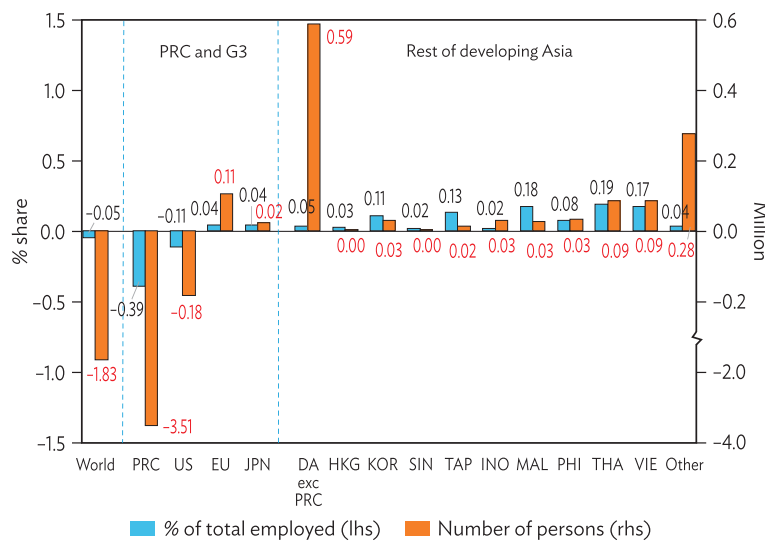

(b) Bilateral escalation scenario

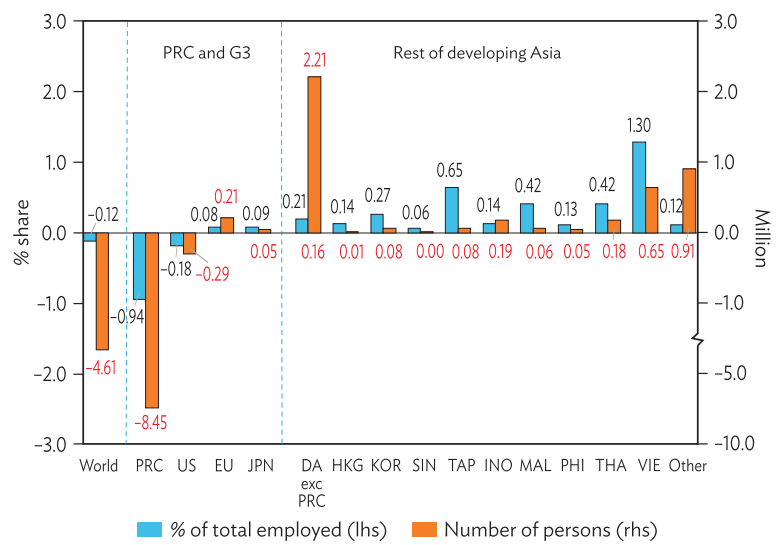

(c) Worse-case scenario

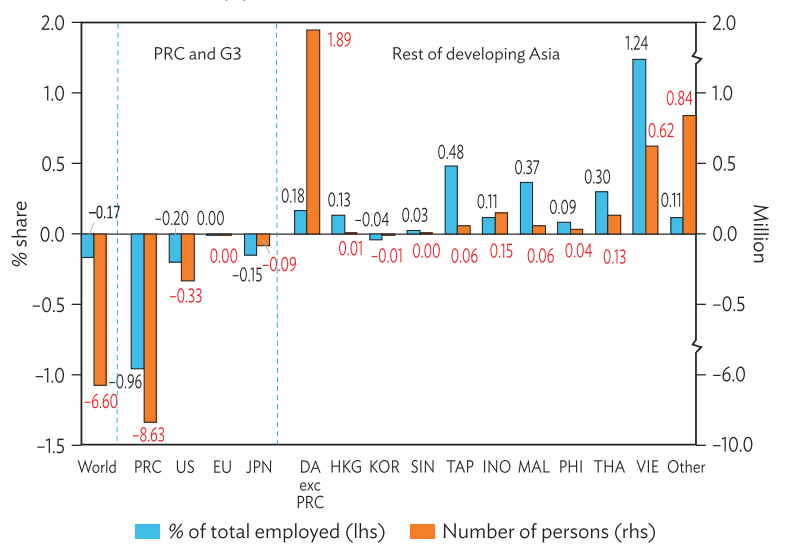

$\mathrm{DA}=$ developing Asia; G3 = European Union, Japan, and United States; EU = European Union; HKG = Hong Kong, China; INO = Indonesia; JPN = Japan; KOR = Republic of Korea; Ihs = left-hand side; MAL = Malaysia; PRC = People's Republic of China; PHI = Philippines; rhs = right-hand side; SIN = Singapore; TAP = Taipei,China; THA = Thailand; US = United States; and VIE = Viet Nam. "Other" here refers to Bangladesh, Brunei Darussalam, Bhutan, Cambodia, Fiji, India, Kazakhstan, the Kyrgyz Republic, the Lao People's Democratic Republic, Maldives, Mongolia, Nepal, Pakistan, and Sri Lanka.

Source: Authors' calculations. 
Table 3: Employment Effects under Worse-Case Scenario, Selected Economies

\begin{tabular}{|c|c|c|c|c|c|c|c|c|}
\hline \multicolumn{3}{|c|}{ People's Republic of China (PRC) } & \multicolumn{3}{|c|}{ United States (US) } & \multicolumn{3}{|c|}{ Developing Asia Excluding the PRC } \\
\hline & $\begin{array}{l}\text { Change from } \\
\text { Baseline } \\
\text { Employment } \\
\text { (Thousand } \\
\text { persons) }\end{array}$ & $\begin{array}{l}\% \text { to Baseline } \\
\text { Employment }\end{array}$ & & $\begin{array}{l}\text { Change from } \\
\text { Baseline } \\
\text { Employment } \\
\text { (Thousand } \\
\text { persons) }\end{array}$ & $\begin{array}{l}\% \text { to Baseline } \\
\text { Employment }\end{array}$ & & $\begin{array}{l}\text { Change from } \\
\text { Baseline } \\
\text { Employment } \\
\text { (Thousand } \\
\text { persons) }\end{array}$ & $\begin{array}{l}\% \text { to Baseline } \\
\text { employment }\end{array}$ \\
\hline Net gain / (loss) & $(8,626)$ & $-1.00 \%$ & Net gain / (loss) & $(329)$ & $-0.20 \%$ & Net gain / (loss) & 1,891 & $0.18 \%$ \\
\hline \multicolumn{3}{|c|}{ Of which: largest losers } & \multicolumn{3}{|c|}{ Of which: largest losers } & \multicolumn{3}{|c|}{ Of which: largest gainers } \\
\hline Agriculture & $(1,863)$ & $-0.2 \%$ & Agriculture & (53) & $-0.03 \%$ & Agriculture & 413 & $0.04 \%$ \\
\hline $\begin{array}{l}\text { Community, social } \\
\text { and personal services }\end{array}$ & $(1,285)$ & $-0.1 \%$ & $\begin{array}{l}\text { Industrial- } \\
\text { purpose } \\
\text { machinery }\end{array}$ & $(48)$ & $-0.03 \%$ & $\begin{array}{l}\text { Textiles and } \\
\text { garments }\end{array}$ & 389 & $0.04 \%$ \\
\hline Retail trade & $(760)$ & $-0.1 \%$ & $\begin{array}{l}\text { Other business } \\
\text { activities }\end{array}$ & $(36)$ & $-0.02 \%$ & Electronics & 288 & $0.03 \%$ \\
\hline $\begin{array}{l}\text { Textiles and } \\
\text { garments }\end{array}$ & $(684)$ & $-0.1 \%$ & Electronics & $(30)$ & $-0.02 \%$ & $\begin{array}{l}\text { Community, } \\
\text { social, and } \\
\text { personal services }\end{array}$ & 133 & $0.01 \%$ \\
\hline Electronics & $(682)$ & $-0.1 \%$ & $\begin{array}{l}\text { Basic metals and } \\
\text { fabricated metal }\end{array}$ & $(30)$ & $-0.02 \%$ & $\begin{array}{l}\text { Leather and } \\
\text { footwear }\end{array}$ & 91 & $0.01 \%$ \\
\hline
\end{tabular}

Note: Values in parentheses "()" indicate a net decrease in employment figures. Baseline employment were generated from model estimates and may differ from official statistics. Source: Authors' calculations. 


\section{Effects on Current Account Balances}

This paper also examines the impacts of tariff measures on external current account balances using the Asian Development Outlook (ADB 2018a) projections produced in April 2018 as the benchmark. These projections reflect growth and external balances assuming the trade conflict had not happened. Model results were used to compute for the size of the current account balances (i) under the current scenario, which is assumed to have fully taken effect in the second half of 2018; and (ii) under the worse-case scenario, which is assumed to take effect starting in the last quarter of 2018 and auto and parts' tariff measures with retaliation kick in the first quarter of 2019. The paper allows partial trade redirection, with 50\% of producers assumed to find new suppliers by 2019.

Under both scenarios, the impact on current account balances is mild (Figure 9). In the worsecase scenario, for example, the current account surplus of the PRC is only marginally narrower, equal to $1.0 \%$ of GDP in 2019 rather than 1.2\% as forecast in the Asian Development Outlook 2018. While the decline in PRC exports is significant, imports are also lower because of both the tariffs imposed by the PRC and indirect effects that reduce demand in the PRC for imported intermediate inputs. In addition, the PRC's GDP is now smaller. For the same reasons, the US sees only a marginally narrower current account deficit, equal to 3.2\% of GDP in 2019 instead of 3.4\% as forecast in the Asian Development Outlook 2018. Similarly, the rest of developing Asia sees only minor impacts on current account balances even in the bilateral escalation scenario. The NIEs see their 2019 current account surplus higher, at $7.3 \%$ of GDP from 7.1\% forecast earlier, and the ASEAN-5 current account surplus equals $1.1 \%$ of GDP in 2019 , not $0.7 \%$ - the benefits to both groups coming from trade redirection. There is no discernible impact on India's current account deficit.

The model results are also used to predict movements in the US-PRC trade balance under the different trade conflict scenarios (Figure 10). In 2017, the US-PRC trade deficit in goods reached $\$ 375.6$ billion. Applying tariff measures under the current scenario, bilateral trade deficit narrows by $11.2 \%$, with expected decreases in US exports to the PRC by $8.6 \%$ and US imports from the PRC by 10.5\%. Under the bilateral escalation scenario, the US trade deficit with the PRC improves by $37.8 \%$, driven by a steeper decline in US imports from the PRC. Given that the PRC's exports to the US are disproportionately at stake in this scenario, the decline in the PRC's nominal output corresponds to higher decline in export production compared to the US. This explains the noticeable decline in US imports from the PRC compared to the PRC's imports from the US. Finally, in a trade conflict involving autos and auto parts, movements in trade deficit were barely observed. However, moving from escalation to worse-case scenario shows a higher decline in US exports to the PRC $(0.13 \%)$ than is observed in its imports from the PRC (0.02\%). This is due to the associated negative impact to US output from trade disruptions in auto supply chains, hence bringing down export production destined to trading partners including the PRC. In contrast, a minimal impact on the PRC's exports to the US is expected given that tariffs were already introduced on all PRC merchandise exports to the US in the previous scenario. 
Figure 9: Current Account Balance under Trade Conflict Scenarios (\% of GDP)

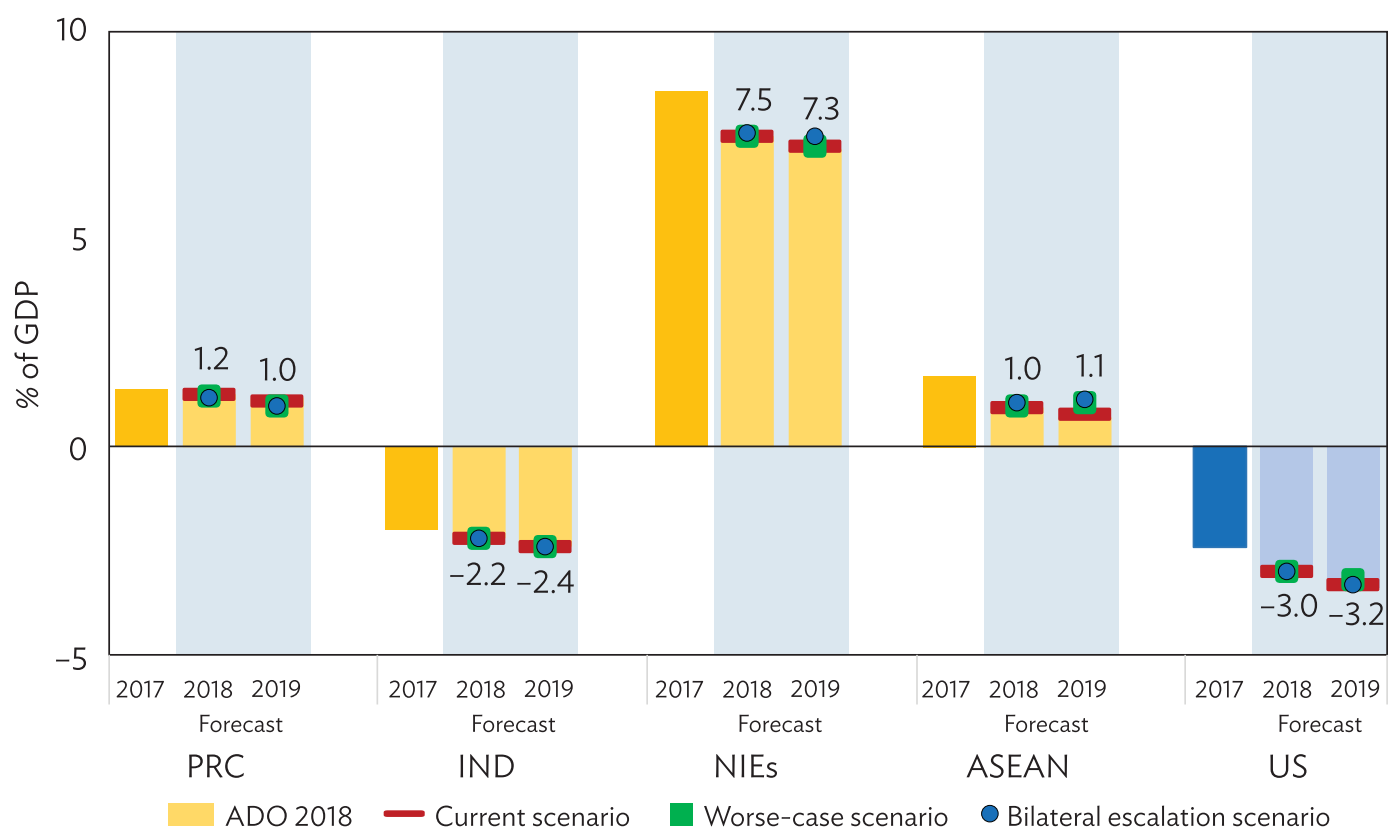

ADO = Asian Development Outlook; ASEAN = Association of Southeast Asian Nations (Indonesia, Malaysia, Philippines, Thailand, and Viet Nam); PRC = People's Republic of China; GDP = gross domestic product; IND = India; NIEs = newly industrialized economies (Hong Kong, China; the Republic of Korea; Singapore; and Taipei,China); US = United States.

Note: Labels refer to the worse-case escalation scenario.

Sources: Asian Development Bank. Asian Development Outlook 2018 database; Authors' calculations.

Figure 10: United States-People's Republic of China Trade Balance Under Trade Conflict Scenarios

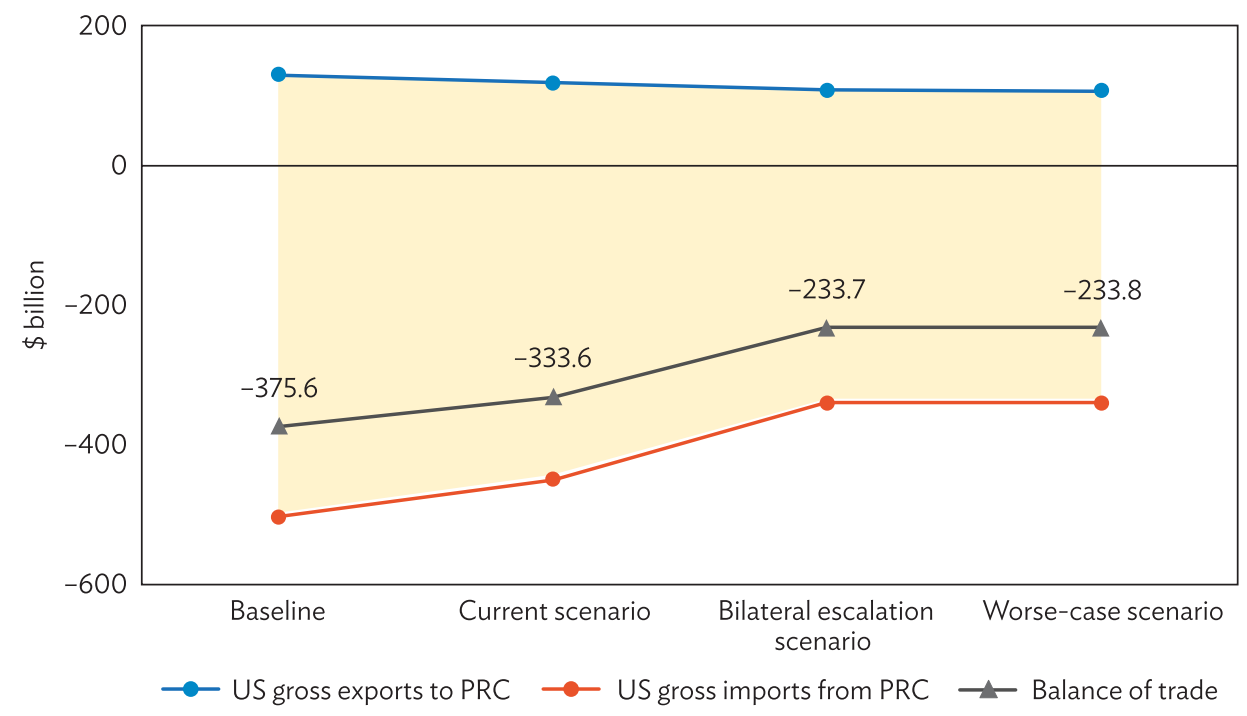

PRC = People's Republic of China, US = United States.

Source: Authors' calculations. 
The simulation does not incorporate other possible counteracting effects since the beginning of the trade conflict, nor does it measure nontariff barriers and investment restrictions. A continuing appreciation of the dollar and stronger-than-expected export demand by the US from developing Asia and elsewhere amid an escalation of US fiscal spending could also undermine its initial intentions to reduce imbalances with Asia through higher tariffs.

\section{SENSITIVITY ANALYSIS}

The response of importers to higher tariffs depends crucially on the assumptions about demand elasticities. Elasticities are typically difficult to estimate accurately at the country-product level, can change over time, and affect much of the literature. Therefore, as a robustness check, various combinations of import demand elasticities are constructed (see Table 4 below).

The elasticity in the first row (denoted $\varepsilon^{\top}$ ) was used as a baseline in the results presented in this paper. Table 5 summarizes the results under the different elasticity assumptions. The simulations reveal that elasticity $\varepsilon^{\top}$ has the highest values on average, hence it yields the highest negative impact on GDP. Estimates reported in the previous section, therefore, are to be interpreted as the upper bound, across all assumptions explored herein.

Table 4: Description of Elasticity Assumptions

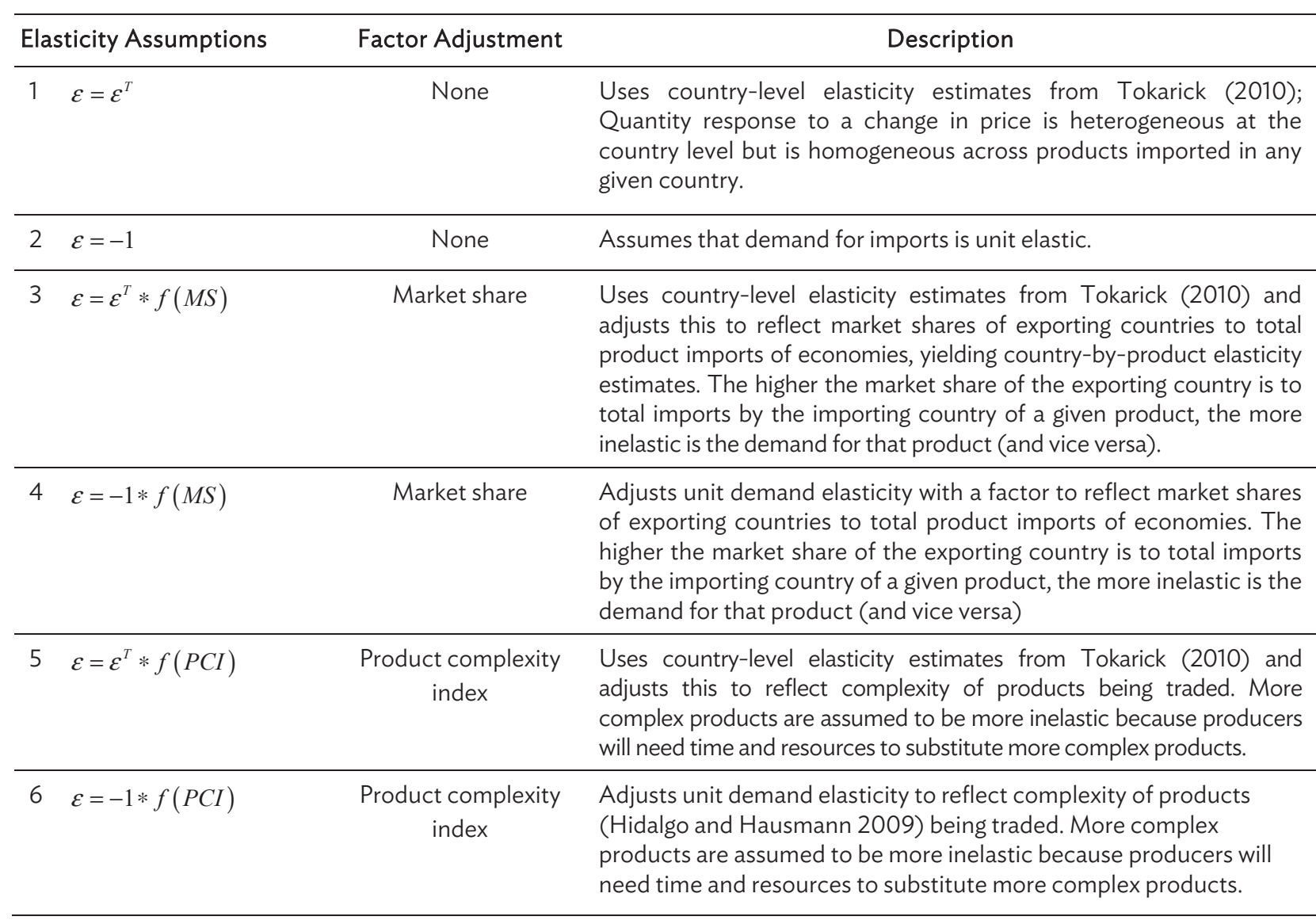

Sources: Hidalgo, César, and Ricardo Hausmann. 2009. "The Building Blocks of Economic Complexity.” Proceedings of the National Academy of Sciences 106 (28): 10570-75; Tokarick, Stephen. 2010. "A Method for Calculating Export Supply and Import Demand Elasticities." IMF Working Paper No. 10/180. 
Table 5: Results of Robustness Checks by Type of Elasticity Assumption (\% change from baseline gross domestic product)

\begin{tabular}{|c|c|c|c|c|c|c|c|c|c|}
\hline \multirow{3}{*}{ Elasticity } & \multirow{3}{*}{$\begin{array}{l}\text { Average } \\
\text { Elasticity }\end{array}$} & \multicolumn{8}{|c|}{ Value Added } \\
\hline & & \multicolumn{4}{|c|}{$\begin{array}{l}\text { Percentage Decline from Baseline } \\
\text { (50\% Trade Redirection) }\end{array}$} & \multicolumn{4}{|c|}{$\begin{array}{l}\text { Percentage Decline from Baseline } \\
\text { (100\% Trade Redirection) }\end{array}$} \\
\hline & & PRC & US & World & $\begin{array}{c}\text { Asia } \\
\text { except } \\
\text { the PRC }\end{array}$ & PRC & US & World & $\begin{array}{c}\text { Asia } \\
\text { except } \\
\text { the PRC }\end{array}$ \\
\hline \multicolumn{10}{|c|}{ Current scenario } \\
\hline $\begin{array}{l}\mathcal{E}=-1 \\
\mathcal{E}^{\wedge} T\end{array}$ & $\begin{array}{l}-1.00 \\
-1.50\end{array}$ & $\begin{array}{l}(0.40) \\
(0.48)\end{array}$ & $\begin{array}{l}(0.09) \\
(0.12)\end{array}$ & $\begin{array}{l}(0.06) \\
(0.08)\end{array}$ & $\begin{array}{l}0.06 \\
0.06\end{array}$ & $\begin{array}{l}(0.38) \\
(0.46)\end{array}$ & $\begin{array}{l}(0.06) \\
(0.08)\end{array}$ & $\begin{array}{l}(0.00) \\
(0.00)\end{array}$ & $\begin{array}{l}0.17 \\
0.18\end{array}$ \\
\hline $1 * f(M S)$ & -1.14 & $(0.10)$ & $(0.05)$ & $(0.02)$ & 0.02 & $(0.09)$ & $(0.05)$ & $(0.00)$ & 0.04 \\
\hline$\varepsilon^{\wedge} T * f(M S)$ & -1.47 & $(0.12)$ & $(0.07)$ & $(0.02)$ & 0.02 & $(0.11)$ & $(0.06)$ & $(0.00)$ & 0.05 \\
\hline $1 * f(P C I)$ & -1.03 & $(0.23)$ & $(0.08)$ & $(0.04)$ & 0.05 & $(0.22)$ & $(0.06)$ & $(0.00)$ & 0.12 \\
\hline$\varepsilon^{\wedge} T * f(P C I)$ & -1.20 & $(0.28)$ & $(0.10)$ & $(0.05)$ & 0.06 & $(0.27)$ & $(0.08)$ & $(0.00)$ & 0.15 \\
\hline AVERAGE & & $(0.27)$ & $(0.09)$ & $(0.05)$ & 0.04 & $(0.25)$ & $(0.07)$ & $(0.00)$ & 0.12 \\
\hline MAX & & $(0.10)$ & $(0.05)$ & $(0.02)$ & 0.06 & $(0.09)$ & $(0.05)$ & $(0.00)$ & 0.18 \\
\hline MIN & & $(0.48)$ & $(0.12)$ & $(0.08)$ & 0.02 & $(0.46)$ & $(0.08)$ & $(0.00)$ & 0.04 \\
\hline \multicolumn{10}{|c|}{ Bilateral escalation scenario } \\
\hline$\varepsilon=-1$ & -1.00 & $(0.85)$ & $(0.13)$ & $(0.12)$ & 0.19 & $(0.81)$ & $(0.06)$ & $(0.00)$ & 0.46 \\
\hline$\varepsilon^{\wedge} T$ & -1.50 & $(1.03)$ & $(0.20)$ & $(0.15)$ & 0.22 & $(0.97)$ & $(0.15)$ & $(0.01)$ & 0.52 \\
\hline $1 * f(M S)$ & -1.14 & $(0.15)$ & $(0.08)$ & $(0.03)$ & 0.04 & $(0.14)$ & $(0.07)$ & $(0.00)$ & 0.09 \\
\hline$\varepsilon^{\wedge} T * f(M S)$ & -1.47 & $(0.18)$ & $(0.11)$ & $(0.04)$ & 0.04 & $(0.17)$ & $(0.10)$ & $(0.00)$ & 0.11 \\
\hline $1 * f(P C I)$ & -1.03 & $(0.76)$ & $(0.15)$ & $(0.10)$ & 0.24 & $(0.73)$ & $(0.12)$ & $(0.01)$ & 0.53 \\
\hline$\varepsilon^{\wedge} T * f(P C I)$ & -1.20 & $(0.76)$ & $(0.16)$ & $(0.11)$ & 0.23 & $(0.73)$ & $(0.12)$ & $(0.01)$ & 0.53 \\
\hline AVERAGE & & $(0.62)$ & $(0.14)$ & $(0.09)$ & 0.16 & $(0.59)$ & $(0.10)$ & $(0.00)$ & 0.37 \\
\hline MAX & & $(0.15)$ & $(0.08)$ & $(0.03)$ & 0.22 & $(0.14)$ & $(0.06)$ & $(0.00)$ & 0.53 \\
\hline MIN & & $(1.03)$ & $(0.20)$ & $(0.15)$ & 0.04 & $(0.97)$ & $(0.15)$ & $(0.01)$ & 0.09 \\
\hline \multicolumn{10}{|c|}{ Worse-case scenario } \\
\hline$\varepsilon=-1$ & -1.00 & $(0.86)$ & $(0.22)$ & $(0.20)$ & 0.12 & $(0.79)$ & 0.03 & $(0.00)$ & 0.43 \\
\hline $\mathcal{E}^{\wedge} T$ & -1.50 & $(1.05)$ & $(0.24)$ & $(0.25)$ & 0.13 & $(0.98)$ & 0.14 & $(0.01)$ & 0.55 \\
\hline $1 * f(M S)$ & -1.14 & $(0.16)$ & $(0.11)$ & $(0.06)$ & $(0.01)$ & $(0.13)$ & $(0.03)$ & $(0.00)$ & 0.06 \\
\hline$\varepsilon^{\wedge} T * f(M S)$ & -1.47 & $(0.19)$ & $(0.16)$ & $(0.08)$ & $(0.01)$ & $(0.16)$ & $(0.06)$ & $(0.00)$ & 0.07 \\
\hline $1 * f(P C I)$ & -1.03 & $(0.77)$ & $(0.18)$ & $(0.14)$ & 0.20 & $(0.72)$ & $(0.05)$ & $(0.01)$ & 0.51 \\
\hline$\varepsilon^{\wedge} T * f(P C I)$ & -1.20 & $(0.77)$ & $(0.22)$ & $(0.15)$ & 0.20 & $(0.72)$ & $(0.09)$ & $(0.01)$ & 0.52 \\
\hline AVERAGE & & $(0.63)$ & $(0.19)$ & $(0.15)$ & 0.10 & $(0.58)$ & $(0.01)$ & $(0.00)$ & 0.36 \\
\hline MAX & & $(0.16)$ & $(0.11)$ & $(0.06)$ & 0.20 & $(0.13)$ & 0.14 & $(0.00)$ & 0.55 \\
\hline MIN & & $(1.05)$ & $(0.24)$ & $(0.25)$ & $(0.01)$ & $(0.98)$ & $(0.09)$ & $(0.01)$ & 0.06 \\
\hline
\end{tabular}

$\mathrm{MIN}=$ minimum, $\mathrm{MAX}=$ maximum, $\mathrm{MS}=$ market share, $\mathrm{PCI}=$ product complexity index, $\mathrm{PRC}=$ People's Republic of China, US = United States. Note: Average elasticities are calculated from the average of import demand elasticities applied to 53,019 product lines in 62 Asian Development Bank Multiregional Input-Output Table economies and the rest of the world. Source: Authors' calculations. 
By introducing adjustments based on product-level characteristics, i.e., market share adjustments or product complexity, the impact on GDP is attenuated. The targeted products may exhibit high complexity (especially for traded parts and components) and that certain trade partners dominate trade in that respect (for instance, in the case of soybeans). Product complexity adjustments however yield higher impact results than market share adjustments. This pattern is more pronounced in the case of the PRC. Looking at market shares, the US is the PRC's dominant trading partner in majority of its imports, capturing an average of 13.2\% market share in 2,232 product lines of the PRC's imports, compared to an average of $4.1 \%$ market share by other trading partners. Therefore, a factor adjustment that accounts for the US' generally larger market share in the PRC's imports will yield lower elasticity on the part of the PRC, thereby generating lower impact arising from tariff-related disruptions. This assumption is valid in the short run, since the PRC might not easily source these products elsewhere, and could prove to be especially rigid for products where the US is the sole supplier, based on 2017 data.10 In the long run, however, buyers may be able to establish new trade links with alternative suppliers and rearrange their supply chain accordingly. Thus, adjusting elasticities for market share or product complexity yields lower estimated effects.

Over the long run, the elasticity will tend to be higher reflecting the possibility of supply adjustments relative to the baseline, but not without significant economic costs along the way. Over the long run, developing Asian economies are positioned to gain from trade. The major factor that explains gains in Asia excluding the PRC is that trade redirection enables these economies to supply products that are in direct competition with goods from the PRC. In the longer run, countries can switch suppliers of intermediate inputs as well as strengthen bilateral trade agreements with other countries. The magnitude of gains is greater under the worse-case scenario as more trade is redirected to Asia excluding the PRC.

\section{CONCLUDING REMARKS}

The current trade conflict clearly has an uneven impact on the region and the world. In sum, the analysis in this paper shows that under a worse-case scenario, where all documented threats and retaliations are carried out, GDP in the PRC would fall by over $1 \%$ and GDP for the US would decline by $0.2 \%$ over a period of 2-3 years. In developing Asia, the effects from the trade conflict are mildly positive, as the region benefits from trade redirection in electronics and textiles. The inclusion of tariffs on autos and auto parts is more damaging for advanced economies (such as the EU and Japan) than in developing Asia. The paper also finds large negative effects on employment for the PRC, while only minor impacts are seen on the trade balance of the US and current account balances generally. This paper shows the advantages and versatility of analyzing trade using the ADB MRIOT database. MRIOTs capture important intersectoral trade links, can be easily extended to analyze new scenarios, and consider other indirect impacts.

However, there are important elements that MRIOT analysis cannot shed light on. First, like other comparative static models, the exercise does distinguish the short-run or long-run effects. The timing of the effects will vary as some impacts, particularly through the direct channel, may occur quickly, while effects through production links and especially trade redirection may take longer to

10 Examples include groundnuts, edible nuts, edible fruits, and certain chemical products such as pyrotechnics among many others. 
appear. One can assume a timing of the direct effects based on effective dates, as shown in Table 1, but there is much less guidance regarding the timing of indirect and trade redirection effects.

Second, there is also uncertainty regarding the amount of trade redirection that will take place. The baseline conservatively assumes that half of trade will be redirected to other countries not affected by the tariffs applied, but the extent of trade redirection could be higher or lower, and could vary across countries. Moreover, the trade redirection effect will take longer the lengthier and more complex the global value chains are, and the ensuing interruption to production could be more protracted. There may be secondary disruption effects from the possibility that production activities that took advantage of low-cost labor in Asia and return to the US due to the tariffs will become highly automated in the US and exacerbate negative employment effects further.

A third limitation of our analysis is that it does not account for the rebalancing of supply and demand in labor and other markets. As a partial equilibrium model of goods markets, it is not a general equilibrium analysis. However, analyses of the trade conflict using CGE models-such as Gentile and $\mathrm{Li}$ (forthcoming), which uses the ADB MRIOT, and Bollen and Rojas-Romagosa (2018) -find effects that are similar in magnitude reported in this paper.

Fourth, the model does not make assumptions about the potential opening of new trade channels, although there is scope for modeling a specific scenario as a reduction of tariffs to zero intraregionally. As concerns over collateral damage from the US-PRC dispute persists, major economies have accelerated ongoing efforts to forge trade agreements within Asia and beyond. Trade agreements reached within the year include Regional Comprehensive Economic Partnership, the AsiaPacific Trade Agreement, the Comprehensive and Progressive Agreement for Trans-Pacific Partnership, the EU-Singapore Free Trade Agreement, the EU-US zero tariff deal, the Japan-EU Economic Partnership Agreement, and the US-Mexico-Canada Agreement.

Fifth, the model does not capture the effects of the trade conflict that work through confidence and future investment, which may be large and already taking effect. The impact through greater economic uncertainty, and the extent of economic disruption that may occur as global production is reallocated is difficult to predict and not captured in the channels explored here. These effects could be substantial as the trade conflict escalates, drags on, and spills over into financial markets. IMF (2018a) incorporates a confidence channel. The effects calculated with an added confidence shock are large, with global GDP lower by $0.5 \%$ at peak impact and most of the loss working through the confidence channel and its negative effects on investment.

How investors will react will be shaped by the extent of uncertainty the trade conflict will cause. Many investors are in a wait-and-see mode, concerned about further escalation or the possibility of a negotiated settlement. The literature on investment under uncertainty shows that businesses will hold off on large changes in investment plans until there is more clarity on the final decision. Even if the trade conflict proves to be temporary, foreign investors are reluctant to look for new suppliers of intermediate goods and sever ties with specialized suppliers or distributors with whom they may have established long-term legal contracts. These relationships are unlikely to be regained in the medium term: evidence from a temporary tariff on steel imports from the PRC in 2004 suggest that US buyers of imported steel were unable to gain back relations with PRC suppliers. The model does not capture the likely hysteresis from the irreversibility of severed links to the global production chains. 
Finally, trade redirection assumes that relative prices across trading partners stay the same. However, if exchange rates or commodity prices change, the effect could be smaller or larger trade reallocation. For example, the PRC renminbi has depreciated by about 10\% against the US dollar between the end of March and mid-November 2018, when the trade conflict began, which counteracts the tariff-induced $10 \%$ and $25 \%$ higher import costs from the PRC, negating a large share of the tariff in dollar terms, which is what matters for US buyers. Also, Asian stock markets have responded with losses to announcements in the short run, potentially having large negative wealth effects by lowering asset prices. The model does not incorporate the possibility of fiscal and monetary policy counteracting the effective costs of the tariffs on producers and consumers.

Over the long term, and if the trade conflict were to become permanent, the impact will be smaller as producers and consumers in new markets adjust prices and stronger trade ties within Asia and between Asia and other regions, such as the EU, compensate for the disruption. Global supply chains built over decades, which underlie international production networks, could allow countries to switch partners to create free trade agreements with other countries.

Evidence of collateral damage from escalating trade dispute between the US and the PRC to other countries across Asia is already emerging, even as exports for the region remained strong. Aggregate exports in the NIEs and ASEAN-5 economies have slowed in the first 8 months of the year compared to the same period a year ago. Exports for the region are likely to expand only slightly going forward as the recovery in manufacturing activity remains fragile and the trade tension shows no sign of abating. Asian policy makers are now looking for ways to cushion their economies from the effects of the trade conflict and to help ensure that trade remains an important driver of growth. For example, expansionary fiscal policies and the recent lowering of the reserve requirement by the central bank of the PRC to boost credit supply should counteract the negative impacts derived in the model. 


\section{APPENDIX}

Table A1: Total Bilateral Trade Affected by the Implemented and Proposed Tariff Lines

\begin{tabular}{|c|c|c|c|}
\hline \multicolumn{4}{|c|}{ Current Scenario } \\
\hline Tariff Action and Sectors Affected & $\begin{array}{c}\text { Average } \\
\text { Tariff } \\
(\%)\end{array}$ & $\begin{array}{l}\text { Change in US-PRC } \\
\text { Bilateral Trade of } \\
\text { Affected Goods } \\
(\$ \text { billion })\end{array}$ & $\begin{array}{l}\text { Change in US-PRC } \\
\text { Bilateral Trade of } \\
\text { Affected Goods } \\
\text { (\% share in US-PRC } \\
\text { bilateral exports) }\end{array}$ \\
\hline \multicolumn{4}{|c|}{ Direct Impact of Additional US Tariffs } \\
\hline US versus World Solar and Washers (Jan 22) & 25 & $-366,372,164$ & -0.09 \\
\hline US versus World Steel (Mar 23) & 25 & $-303,933,152$ & -0.07 \\
\hline US versus World Aluminum (Mar 23) & 10 & $-289,523,678$ & -0.07 \\
\hline US versus PRC $\$ 34$ billion (Jul 6) & 25 & $-9,228,928,851$ & -2.14 \\
\hline Basic Metals and Fabricated Metal & 25 & $-225,114,089$ & -0.05 \\
\hline Chemicals and Chemical Products & 25 & $-842,996,525$ & -0.20 \\
\hline Electrical and Optical Equipment & 25 & $-3,940,976,981$ & -0.92 \\
\hline Machinery, nec & 25 & $-4,084,592,153$ & -0.95 \\
\hline Other Nonmetallic Mineral & 25 & $-2,338,608$ & -0.001 \\
\hline Rubber and Plastics & 25 & $-83,694,941$ & -0.02 \\
\hline Textiles and Textile Products & 25 & $-47,952,110$ & -0.01 \\
\hline Transport Equipment & 25 & $-1,263,443$ & -0.0003 \\
\hline US versus PRC $\$ 16$ billion (Aug 23) & 25 & $-4,145,528,660$ & -0.96 \\
\hline Basic Metals and Fabricated Metal & 25 & $-287,190,006$ & -0.07 \\
\hline Chemicals and Chemical Products & 25 & $-1,329,485,393$ & -0.31 \\
\hline Electrical and Optical Equipment & 25 & $-910,730,456$ & -0.21 \\
\hline Leather, Leather and Footwear & 25 & $-436,786,651$ & -0.10 \\
\hline Machinery, nec & 25 & $-1,044,807,734$ & -0.24 \\
\hline Mining and Quarrying & 25 & $-207,923$ & 0.00 \\
\hline Other Nonmetallic Mineral & 25 & $-5,865,773$ & -0.001 \\
\hline Transport Equipment & 25 & $-130,454,723$ & -0.03 \\
\hline US versus PRC $\$ 200$ billion (Sep) & 10 & $-22,945,556,344$ & -5.33 \\
\hline Agriculture, Hunting, Forestry and Fishing & 10 & $-95,940,071$ & -0.02 \\
\hline Basic Metals and Fabricated Metal & 10 & $-1,447,864,821$ & -0.34 \\
\hline Chemicals and Chemical Products & 10 & $-3,715,102,943$ & -0.86 \\
\hline Coke, Refined Petroleum and Nuclear Fuel & 10 & $-155,241,522$ & -0.04 \\
\hline Electrical and Optical Equipment & 12 & $-7,528,633,277$ & -1.75 \\
\hline Electricity, Gas and Water Supply & 10 & 0 & 0.00 \\
\hline Food, Beverages and Tobacco & 10 & $-1,257,910,642$ & -0.29 \\
\hline Leather, Leather and Footwear & 10 & $-1,674,601,799$ & -0.39 \\
\hline Machinery, nec & 13 & $-2,374,985,336$ & -0.55 \\
\hline Manufacturing, nec; Recycling & 10 & $-1,572,450$ & -0.0004 \\
\hline Mining and Quarrying & 11 & $-119,422,471$ & -0.03 \\
\hline
\end{tabular}


30 | ADB Economics Working Paper Series No. 566

Table A1 continued

\begin{tabular}{|c|c|c|c|}
\hline \multicolumn{4}{|c|}{ Current Scenario } \\
\hline Tariff Action and Sectors Affected & $\begin{array}{c}\text { Average } \\
\text { Tariff } \\
(\%)\end{array}$ & $\begin{array}{l}\text { Change in US-PRC } \\
\text { Bilateral Trade of } \\
\text { Affected Goods } \\
\text { ( } \$ \text { billion) }\end{array}$ & $\begin{array}{c}\text { Change in US-PRC } \\
\text { Bilateral Trade of } \\
\text { Affected Goods } \\
\text { (\% share in US-PRC } \\
\text { bilateral exports) }\end{array}$ \\
\hline \multicolumn{4}{|c|}{ Direct Impact of Additional US Tariffs } \\
\hline Other Community, Social and Personal Services & 10 & $-33,815,254$ & -0.01 \\
\hline Other Nonmetallic Mineral & 10 & $-583,894,411$ & -0.14 \\
\hline Post and Telecommunications & 10 & $-70,540$ & 0.00 \\
\hline Pulp, Paper, Paper , Printing and Publishing & 10 & $-178,454,956$ & -0.04 \\
\hline Renting of M\&Eq and Other Business Activities & 10 & $-1,377,714$ & -0.0003 \\
\hline Rubber and Plastics & 11 & $-256,958,648$ & -0.06 \\
\hline Textiles and Textile Products & 10 & $-1,011,007,212$ & -0.23 \\
\hline Transport Equipment & 12 & $-2,385,167,501$ & -0.55 \\
\hline Wood and Products of Wood and Cork & 10 & $-123,534,775$ & -0.03 \\
\hline \multicolumn{4}{|c|}{ Direct Impact of Additional PRC Tariffs } \\
\hline PRC versus US $\$ 3$ billion (Apr 2 ) & 17 & $-819,288,776$ & -0.63 \\
\hline Agriculture, Hunting, Forestry and Fishing & 16 & $-138,410,351$ & -0.11 \\
\hline Basic Metals and Fabricated Metal & 17 & $-286,764,606$ & -0.22 \\
\hline Food, Beverages and Tobacco & 18 & $-394,113,820$ & -0.30 \\
\hline PRC versus US $\$ 34$ billion (Jul 6) & 23 & $-10,915,789,387$ & -8.40 \\
\hline Agriculture, Hunting, Forestry and Fishing & 21 & $-5,552,938,717$ & -4.27 \\
\hline Electrical and Optical Equipment & 25 & $-228,727,928$ & -0.18 \\
\hline Food, Beverages and Tobacco & 24 & $-982,813,647$ & -0.76 \\
\hline Manufacturing, nec; Recycling & 25 & $-24,600,350$ & -0.02 \\
\hline Transport Equipment & 25 & $-4,126,708,745$ & -3.18 \\
\hline PRC versus US \$16 billion (Aug 23) & 23 & $-6,952,615,041$ & -5.35 \\
\hline Agriculture, Hunting, Forestry and Fishing & 25 & 0 & 0.00 \\
\hline Basic Metals and Fabricated Metal & 18 & $-50,035,057$ & -0.04 \\
\hline Chemicals and Chemical Products & 23 & $-426,580,933$ & -0.33 \\
\hline Coke, Refined Petroleum and Nuclear Fuel & 23 & $-933,273,993$ & -0.72 \\
\hline Electrical and Optical Equipment & 21 & $-540,732,747$ & -0.42 \\
\hline Electricity, Gas and Water Supply & 25 & $-1,219$ & 0.00 \\
\hline Food, Beverages and Tobacco & 23 & $-262,104,036$ & -0.20 \\
\hline Leather, Leather and Footwear & 25 & $-266,223,588$ & -0.20 \\
\hline Machinery, nec & 17 & $-6,246,420$ & -0.005 \\
\hline Mining and Quarrying & 25 & $-1,141,418,354$ & -0.88 \\
\hline Other Nonmetallic Mineral & 18 & $-29,556,016$ & -0.02 \\
\hline Pulp, Paper, Paper, Printing and Publishing & 25 & $-276,843,759$ & -0.21 \\
\hline Textiles and Textile Products & 23 & $-299,245,068$ & -0.23 \\
\hline Transport Equipment & 25 & $-2,720,309,094$ & -2.09 \\
\hline Wood and Products of Wood and Cork & 18 & $-44,758$ & 0.00 \\
\hline
\end{tabular}




\begin{tabular}{|c|c|c|c|}
\hline \multicolumn{4}{|c|}{ Current Scenario } \\
\hline Tariff Action and Sectors Affected & $\begin{array}{c}\text { Average } \\
\text { Tariff } \\
(\%)\end{array}$ & $\begin{array}{l}\text { Change in US-PRC } \\
\text { Bilateral Trade of } \\
\text { Affected Goods } \\
\text { ( } \$ \text { billion) }\end{array}$ & $\begin{array}{l}\text { Change in US-PRC } \\
\text { Bilateral Trade of } \\
\text { Affected Goods } \\
\text { (\% share in US-PRC } \\
\text { bilateral exports) }\end{array}$ \\
\hline \multicolumn{4}{|c|}{ Direct Impact of Additional PRC Tariffs } \\
\hline PRC versus US $\$ 60$ billion (Sep) & 18 & $-8,640,271,975$ & -6.65 \\
\hline Agriculture, Hunting, Forestry and Fishing & 20 & $-160,081,047$ & -0.12 \\
\hline Basic Metals and Fabricated Metal & 19 & $-389,712,666$ & -0.30 \\
\hline Chemicals and Chemical Products & 16 & $-1,545,586,796$ & -1.19 \\
\hline Coke, Refined Petroleum and Nuclear Fuel & 17 & $-228,711,825$ & -0.18 \\
\hline Electrical and Optical Equipment & 16 & $-1,917,681,208$ & -1.48 \\
\hline Food, Beverages and Tobacco & 17 & $-889,251,925$ & -0.68 \\
\hline Leather, Leather and Footwear & 19 & $-479,156,355$ & -0.37 \\
\hline Machinery, nec & 17 & $-1,322,720,274$ & -1.02 \\
\hline Manufacturing, nec; Recycling & 17 & $-8,452,812$ & -0.01 \\
\hline Mining and Quarrying & 20 & $-475,791,757$ & -0.37 \\
\hline Other Community, Social and Personal Services & 12 & $-1,636,821$ & -0.001 \\
\hline Other Nonmetallic Mineral & 17 & $-185,923,390$ & -0.14 \\
\hline Post and Telecommunications & 15 & $-15,125,957$ & -0.01 \\
\hline Pulp, Paper, Paper, Printing and Publishing & 15 & $-244,059,038$ & -0.19 \\
\hline Renting of M\&Eq and Other Business Activities & 12 & $-49,694$ & 0.00 \\
\hline Rubber and Plastics & 12 & $-32,919,091$ & -0.03 \\
\hline Textiles and Textile Products & 22 & $-339,131,718$ & -0.26 \\
\hline Transport Equipment & 17 & $-27,769,023$ & -0.02 \\
\hline Wood and Products of Wood and Cork & 21 & $-376,510,576$ & -0.29 \\
\hline
\end{tabular}

$M \& E q=$ machinery and equipment, nec $=$ not elsewhere classified, $P R C=$ People's Republic of China, US = United States.

Source: Calculations based on United States Census Bureau. 2017. USA Trade Online Database. https://usatrade.census.gov/ (accessed July 31, 2018); BACI. BACI International Trade Database. http://www.cepii.fr/CEPII/en/bdd_modele/presentation.asp?id=1 (accessed July 2018). 
Table A2: Summary of Literature on United States-People's Republic of China Trade Conflict

\begin{tabular}{|c|c|c|c|c|c|}
\hline Study Name & $\begin{array}{l}\text { Authors and } \\
\text { Affiliation }\end{array}$ & Approach & $\begin{array}{l}\text { Underlying } \\
\text { Scenarios }\end{array}$ & Data & Results \\
\hline $\begin{array}{l}\text { Economic } \\
\text { Impacts of the } \\
\text { Possible PRC-US } \\
\text { Trade War }\end{array}$ & $\begin{array}{l}\text { Chunding Li, } \\
\text { Chuantian } \\
\text { He, and } \\
\text { Chuangwei } \\
\text { Lin }\end{array}$ & $\begin{array}{l}\text { - Global general } \\
\text { equilibrium model } \\
\text { - Applied elasticity of } \\
\text { around } 2 \text { (Whalley } \\
\text { and Wang 2010) } \\
\text { due to lack of } \\
\text { country-level } \\
\text { elasticities of } \\
\text { demand and } \\
\text { production. } \\
\text { - Sensitivity analysis } \\
\text { on varying elasticity } \\
\text { levels }\end{array}$ & $\begin{array}{l}\text { The first } \\
\text { scenario } \\
\text { focused on the } \\
\text { PRC-US tariff } \\
\text { trade war, which } \\
\text { is characterized } \\
\text { by mutual } \\
\text { retaliation tariff } \\
\text { measures from } \\
\text { the US and the } \\
\text { PRC }\end{array}$ & $\begin{array}{l}\text { - Base year is } \\
2013 \\
\text { - Includes } 29 \\
\text { countries }\end{array}$ & $\begin{array}{l}\text { - Referring to a } \\
\text { scenario where the } \\
\text { US and the PRC } \\
\text { mutually impose } \\
\text { tariffs of } 30 \% \text { on } \\
\text { imports, GDP in PRC } \\
\text { is seen to decline by } \\
1.15 \text { percentage } \\
\text { points while the US } \\
\text { see an increase of } \\
\text { 0.037 percentage } \\
\text { points in GDP. The } \\
\text { disparity in GDP } \\
\text { widens as import } \\
\text { tariff rates are } \\
\text { increased. } \\
\text { - The effects of the } \\
\text { PRC-US tariff war to } \\
\text { the world are } \\
\text { negative in terms of } \\
\text { GDP, manufacturing } \\
\text { production, } \\
\text { employment, and } \\
\text { trade. } \\
\text { - Authors concluded } \\
\text { that trade war with } \\
\text { the US will hurt the } \\
\text { PRC, but not deeply. } \\
\text { - Sensitivity analysis } \\
\text { on varying } \\
\text { elasticities show that } \\
\text { effects are nearly the } \\
\text { same. }\end{array}$ \\
\hline $\begin{array}{l}\text { Trade Wars: } \\
\text { Economic } \\
\text { impacts of US } \\
\text { tariff increases } \\
\text { and retaliations } \\
\text { An international } \\
\text { perspective } \\
\text { Netherlands } \\
\text { Bureau for } \\
\text { Economic Policy } \\
\text { Analysis (CPB) } \\
\text { Background } \\
\text { Document } \\
\text { (19 June 2018) }\end{array}$ & $\begin{array}{l}\text { Johannes } \\
\text { Bollen } \\
\text { Hugo Rojas- } \\
\text { Romagosa }\end{array}$ & $\begin{array}{l}\text { - Computational } \\
\text { general equilibrium } \\
\text { (CGE) model by } \\
\text { WorldScan (see } \\
\text { Lejour et al. 2006). } \\
\text { - Employ recursive } \\
\text { dynamic model that } \\
\text { provides year-to-year } \\
\text { estimations between } \\
2011 \text { and } 2030 . \\
\text { - Sensitivity analysis } \\
\text { deploys two changes: } \\
\text { (i) change in size of } \\
\text { elasticities, and } \\
\text { (ii) introducing } \\
\text { monopolistic } \\
\text { competition setting } \\
\text { and endogenous } \\
\text { labor supply } \\
\text { mechanisms. }\end{array}$ & $\begin{array}{l}\text { - The scenario } 3 \\
\text { covers steel } \\
\text { and aluminum } \\
\text { mutual } \\
\text { retaliation } \\
\text { among affected } \\
\text { economies and } \\
\text { the US-PRC } \\
\text { trade sanctions } \\
\text { as of June } 2018 \\
\text { - Scenario } 4 \text { adds } \\
\text { the US } \\
\text { unilateral 25\% } \\
\text { tariff on motor } \\
\text { vehicles from } \\
\text { the EU but } \\
\text { without } \\
\text { retaliation }\end{array}$ & $\begin{array}{l}\text { - GTAP } \\
\text { database } \\
\text { (version } 9 \\
\text { with base- } \\
\text { year 2011) } \\
\text { - } 29 \text { goods and } \\
\text { service } \\
\text { sectors } \\
\text { - Includes } 30 \\
\text { countries } \\
\text { and regions }\end{array}$ & $\begin{array}{l}\text { - } \text { Results from } \\
\text { Scenario } 3 \text { show that } \\
\text { the PRC bears the } \\
\text { largest losses with a } \\
\text { permanent real GDP } \\
\text { loss of } 1.2 \% \text { and a } \\
\text { decrease in its total } \\
\text { exports of around } \\
9 \% \text {. The US is also } \\
\text { negatively affected } \\
\text { with } 0.3 \% \text { real GDP } \\
\text { loss } \\
\text { - Incremental effects } \\
\text { in Scenario } 4 \\
\text { appear to be } \\
\text { limited, where the } \\
\text { EU takes a GDP } \\
\text { decline of } 0.2 \% \\
\text { when compared } \\
\text { with scenario } 3 \text {. } \\
\text { Germany is set to }\end{array}$ \\
\hline
\end{tabular}




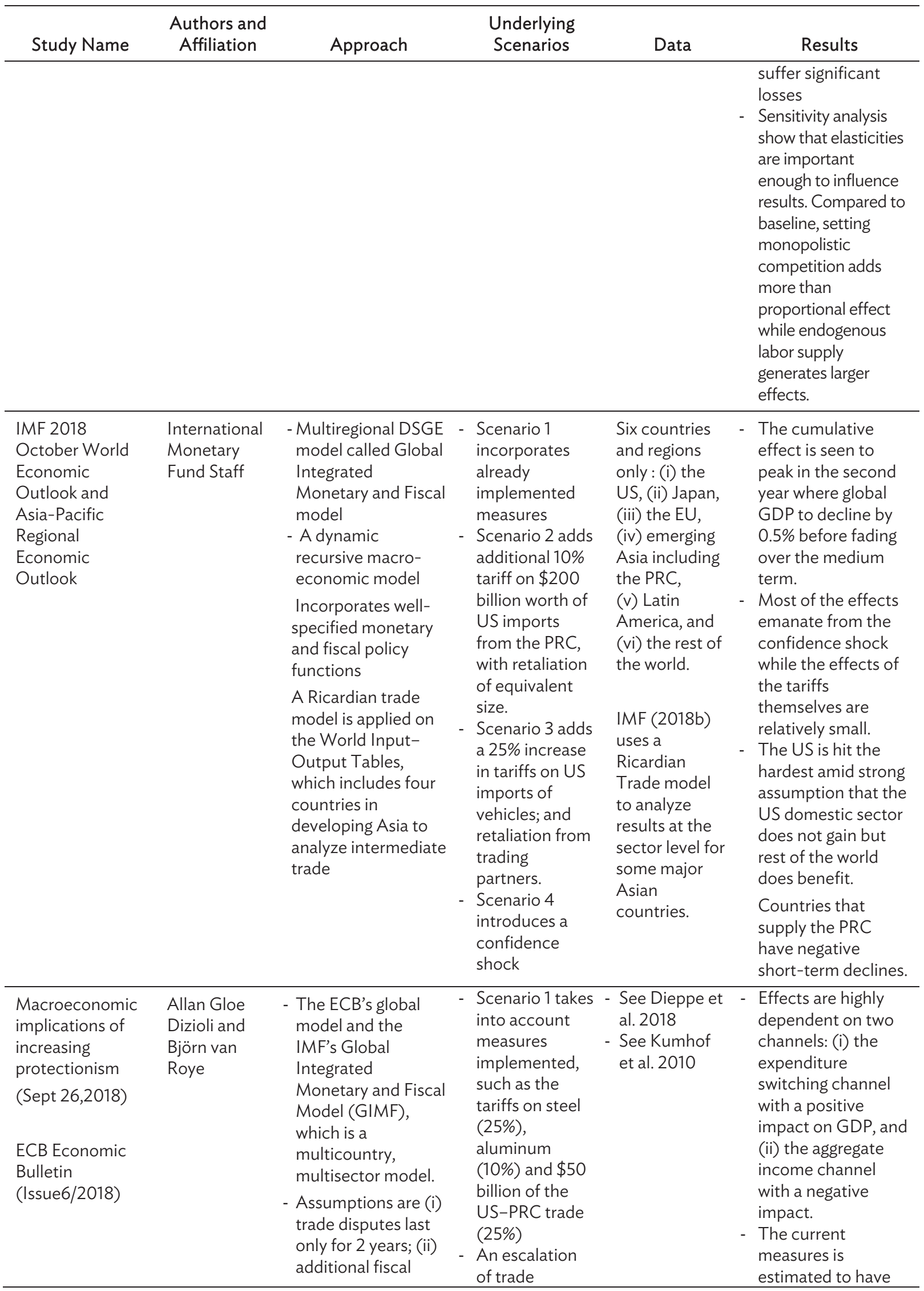


Table A2 continued

\begin{tabular}{|c|c|c|c|c|c|}
\hline Study Name & $\begin{array}{c}\text { Authors and } \\
\text { Affiliation }\end{array}$ & Approach & $\begin{array}{l}\text { Underlying } \\
\text { Scenarios }\end{array}$ & Data & Results \\
\hline & & $\begin{array}{l}\text { revenues generated } \\
\text { by tariff increases } \\
\text { are used to reduce } \\
\text { budget deficits, } \\
\text { rather than to } \\
\text { support demand; } \\
\text { (iii) monetary policy } \\
\text { and exchange rates } \\
\text { are assumed to } \\
\text { react endogenously } \\
\text { in all countries; and } \\
\text { (iv) confidence } \\
\text { effects as changes } \\
\text { in equity and bond } \\
\text { risk premia. }\end{array}$ & $\begin{array}{l}\text { tensions is } \\
\text { depicted by the } \\
\text { US imposing } \\
\text { tariffs on all } \\
\text { imports by } 10 \\
\text { percentage } \\
\text { points with } \\
\text { retaliation from } \\
\text { trading } \\
\text { partners. }\end{array}$ & & $\begin{array}{l}\text { only a marginal } \\
\text { effect on global } \\
\text { economic activity, } \\
\text { as the targeted } \\
\text { products represent } \\
\text { only a small part of } \\
\text { world trade. } \\
\text { - The direct trade } \\
\text { channel lowers US } \\
\text { economic activity } \\
\text { by 1.5\% in the first } \\
\text { year. By contrast, in } \\
\text { the PRC, the trade } \\
\text { effect on GDP is } \\
\text { initially slightly } \\
\text { positive, although } \\
\text { the gains diminish } \\
\text { over time. } \\
\text { - The deterioration in } \\
\text { confidence has } \\
\text { significant adverse } \\
\text { effects on global } \\
\text { activity with global } \\
\text { output around } \\
\text { 0.75\% lower in the } \\
\text { first year. }\end{array}$ \\
\hline
\end{tabular}

DSGE = dynamic stochastic general equilibrium, ECB = European Central Bank, EU = European Union, GDP = gross domestic product, GTAP = Global Trade Analysis Project, IMF = International Monetary Fund, PRC = People's Republic of China, US = United States.

Note: The Group of Twenty (G20) countries is comprised of Argentina, Australia, Brazil, Canada, the People's Republic of China, the

European Union, France, Germany, India, Indonesia, Italy, Japan, Mexico, the Republic of Korea, the Russian Federation, Saudi Arabia, South Africa, Turkey, the United Kingdom, and the United States.

Source: Authors' compilation. 
Table A3: Summary of Impact of Trade Conflict under Each Scenario, Developing Asia

\begin{tabular}{|c|c|c|c|c|c|c|c|c|c|}
\hline \multirow[b]{2}{*}{ Country } & \multicolumn{3}{|c|}{$\begin{array}{l}\text { Effect on Gross Domestic Product } \\
(\%)\end{array}$} & \multicolumn{3}{|c|}{$\begin{array}{l}\text { Employment } \\
\text { (Thousands) }\end{array}$} & \multicolumn{3}{|c|}{$\begin{array}{l}\text { Exports } \\
(\%)\end{array}$} \\
\hline & Current & $\begin{array}{l}\text { Bilateral } \\
\text { Escalation }\end{array}$ & $\begin{array}{l}\text { Worse } \\
\text { Case }\end{array}$ & Current & $\begin{array}{l}\text { Bilateral } \\
\text { Escalation }\end{array}$ & $\begin{array}{l}\text { Worse } \\
\text { Case }\end{array}$ & Current & $\begin{array}{l}\text { Bilateral } \\
\text { Escalation }\end{array}$ & $\begin{array}{l}\text { Worse } \\
\text { Case }\end{array}$ \\
\hline Bangladesh & 0.0 & 0.2 & 0.2 & 18 & 118 & 117 & 0.3 & 2.0 & 2.0 \\
\hline $\begin{array}{l}\text { Brunei } \\
\text { Darussalam }\end{array}$ & 0.1 & 0.1 & 0.0 & 0 & 0 & 0 & 0.1 & 0.2 & 0.1 \\
\hline Bhutan & 0.0 & 0.0 & 0.0 & 0 & 0 & 0 & 0.0 & 0.0 & 0.1 \\
\hline Cambodia & 0.2 & 1.1 & 1.1 & 60 & 94 & 86 & 1.4 & 6.6 & 6.5 \\
\hline Fiji & 0.1 & 0.1 & 0.1 & 0 & 1 & 1 & 0.3 & 0.4 & 0.4 \\
\hline $\begin{array}{l}\text { Hong Kong, } \\
\text { China }\end{array}$ & 0.0 & 0.1 & 0.1 & 1 & 6 & 5 & 0.2 & 0.7 & 0.6 \\
\hline Indonesia & 0.0 & 0.1 & 0.1 & 32 & 186 & 151 & 0.2 & 0.8 & 0.7 \\
\hline India & 0.0 & 0.1 & 0.1 & 164 & 532 & 464 & 0.2 & 0.7 & 0.5 \\
\hline Kazakhstan & 0.0 & 0.0 & 0.0 & 2 & 2 & 6 & 0.0 & 0.1 & 0.1 \\
\hline $\begin{array}{l}\text { Kyrgyz } \\
\text { Republic }\end{array}$ & 0.1 & 0.1 & 0.1 & 2 & 4 & 9 & 0.2 & 0.3 & 0.3 \\
\hline $\begin{array}{l}\text { Republic of } \\
\text { Korea }\end{array}$ & 0.1 & 0.3 & 0.0 & 31 & 78 & -11 & 0.6 & 1.5 & 0.1 \\
\hline $\begin{array}{l}\text { Lao People's } \\
\text { Democratic } \\
\text { Republic }\end{array}$ & 0.1 & 0.4 & 0.4 & 5 & 35 & 36 & 0.2 & 1.3 & 1.3 \\
\hline Malaysia & 0.2 & 0.5 & 0.5 & 27 & 63 & 55 & 0.8 & 1.9 & 1.8 \\
\hline Maldives & 0.0 & 0.0 & 0.0 & 0 & 0 & 0 & 0.0 & 0.0 & 0.0 \\
\hline Mongolia & -0.1 & -0.3 & -0.3 & 0 & -1 & -1 & -0.1 & -0.5 & -0.5 \\
\hline Nepal & 0.0 & 0.0 & 0.0 & 3 & 12 & 11 & 0.2 & 1.2 & 1.2 \\
\hline Pakistan & 0.0 & 0.1 & 0.1 & 20 & 91 & 89 & 0.3 & 1.6 & 1.6 \\
\hline Philippines & 0.1 & 0.2 & 0.1 & 33 & 53 & 36 & 1.1 & 1.6 & 1.2 \\
\hline $\begin{array}{l}\text { People's } \\
\text { Republic of } \\
\text { China }\end{array}$ & -0.5 & -1.0 & -1.1 & $-3,509$ & $-8,452$ & $-8,626$ & -3.6 & -7.8 & -7.8 \\
\hline Singapore & 0.0 & 0.1 & 0.0 & 1 & 2 & 1 & 0.1 & 0.2 & 0.1 \\
\hline Sri Lanka & 0.0 & 0.2 & 0.2 & 2 & 24 & 24 & 0.2 & 1.7 & 1.7 \\
\hline Taipei,China & 0.1 & 0.6 & 0.4 & 16 & 78 & 58 & 0.5 & 2.1 & 1.6 \\
\hline Thailand & 0.1 & 0.3 & 0.2 & 85 & 184 & 132 & 0.5 & 1.1 & 0.8 \\
\hline Viet Nam & 0.2 & 2.2 & 2.1 & 87 & 652 & 620 & 0.8 & 7.3 & 7.0 \\
\hline
\end{tabular}

Source: Authors' calculations. 


\section{REFERENCES}

Arbatli, Elif, and Gee Hee Hong. 2016. "Singapore's Export Elasticities: A Disaggregated Look into the Role of Global Value Chains and Economic Complexity.” IMF Working Paper No. 16/52.

Asian Development Bank (ADB). 2015. "Understanding the Statistics on Global Value Chains." Technical Appendix to Part IV of the Key Indicators for Asia and the Pacific 2015. Manila.

2018a. Asian Development Outlook 2018: How Technology Affects Jobs. Manila.

2018b. Asian Development Outlook 2018 Update: Maintaining Stability amid Heightened Uncertainty. Manila.

Bollen, Johannes, and Hugo Rojas-Romagosa. 2018. "Trade Wars: Economic Impacts of US Tariff Increases and Retaliations: An International Perspective.” CPB Background Document.

CEPII. BACl: International Trade Database. http://www.cepii.fr/CEPII/en/bdd_modele/presentation.asp?id=1 (accessed July 31, 2018).

Dieppe, Alistair, Georgios Georgiadis, Martino Ricci, Ine Van Robays, and Björn van Roye. 2018. "ECB-Global: Introducing the ECB's Global Macroeconomic Model for Spillover Analysis." Economic Modeling 72: 78-98.

Dizioli, Allan Gloe, and Björn van Roye. 2018. ECB Economic Bulletin, Issue 6. European Central Bank.

Feenstra, Robert, and Akira Sasahara. 2017. "The 'China Shock', Exports and U.S. Employment: A Global Input-Output Analysis.” National Bureau of Economic Research Working Paper No. 24022.

Felettigh, Alberto, and Stefano Federico. 2010. "Measuring the Price Elasticity of Import Demand in the Destination Markets of Italian Export.” Bank of Italy Economic Working Paper No. 776.

Gentile, Elisabetta, and Gen Li. Forthcoming. "Assessing the Economic Impact of the US-PRC Tariff Conflict Using a Multiregional CGE Model.” ADB Economics Working Paper Series.

Hanemann, Thilo. 2018. "Arrested Development: Chinese FDI in the US in 1H 2018." https://rhg.com/research/arresteddevelopment-chinese-fdi-in-the-us-in-1h-2018.

Hidalgo, César, and Ricardo Hausmann. 2009. "The Building Blocks of Economic Complexity." Proceedings of the National Academy of Sciences 106 (28): 10570-75.

Imbs, Jean, and Isabelle Mejean. 2017. "Trade Elasticities." Review of International Economics 25 (2): 383-402.

International Monetary Fund (IMF). 2018a. World Economic Outlook 2018: Challenges to Steady Growth. Washington, DC. https://www.imf.org/en/Publications/WEO/Issues/2018/09/24/worldeconomic-outlook-october-2018. 
2018b. "The Evolving Role of Trade in Asia: Opening a New Chapter." In Regional Economic Outlook: Asia and Pacific. Washington, DC. https://www.imf.org/en/Publications/REO/APAC/Issues/2018/10/05/areo1012.

Kumhof, Michael, Douglas Laxton, Dirk Muir, and Susanna Mursula. 2010. "The Global Integrated Monetary and Fiscal Model (GIMF) - Theoretical Structure.” IMF Working Paper No. 10/34.

Kutlina-Dimitrova, Zornitsa, and Csilla Lakatos. 2017. "The Global Costs of Protectionism.” World Bank Policy Research Working Paper No. 8277.

Lejour, Arjan, Paul Veenendaal, Gerard Verweij, and Nico van Leeuwen. 2006. "WorldScan: A Model for International Economic Policy Analysis." CPB Document 111. The Hague.

Leontief, Wassily W. 1936. "Quantitative Input-Output Relations in the Economic System of the United States." Review of Economics and Statistics 18 (3): 105-25.

$\mathrm{Li}$, Chunding, Chuantian He, and Chuangwei Lin. 2018. "Economic Impacts of the Possible China-US Trade War." Emerging Markets Finance and Trade 54: 1557-77.

Los, Bart, Marcel P. Timmer, and Gaaitzen J. de Vries. 2015. "How Important are Exports for Job Growth in China?: A Demand Side Analysis.” Journal of Comparative Advantage 43 (1): 19-32.

Reimer, Jeffrey J., Xiaojuan Zheng, and Mark J. Gehlhar. 2013. "Export Demand Elasticity Estimation for Major U.S. Crops.” Journal of Agricultural and Applied Economics 44 (4): 501-15.

Reuters. 2018. U.S. Firms in China Feeling 'Clear and Far Reaching’ Trade War Pinch: Survey. 13 Sept. https://www.nytimes.com/reuters/2018/09/13/business/13reuters-usa-trade-chinasurvey.html.

Timmer, Marcel P., Abdul Azeez Erumban, Bart Los, Robert Stehrer, and Gaaitzen J. de Vries. 2014. "Slicing up Global Value Chains." Journal of Economic Perspectives 28 (2): 99-118.

Tokarick, Stephen. 2010. "A Method for Calculating Export Supply and Import Demand Elasticities.” IMF Working Paper No. 10/180.

United States Census Bureau. 2017. USA Trade Online Database. https://usatrade.census.gov/ (accessed July 31, 2018).

Wang, Zhi, Shang-Jin Wei, and Kunfu Zhu. 2018. "Quantifying International Production Sharing at the Bilateral and Sector Levels." National Bureau of Economic Research Working Paper No. 19677.

Whalley, John, and Li Wang. 2010. "The Impact of Renminbi Appreciation on Trade Flows and Reserve Accumulation on a Monetary Trade Model." Economic Modelling 28 (1): 614-21. doi:10.1016/j.econmod.2010.06.010.

Zhai, Fan, and Juzhong Zhuang. 2017. "How Would a US Tariff Hike Affect the Global Economy: A General Equilibrium Assessment.” Unpublished. 


\section{The Impact of Trade Conflict on Developing Asia}

This working paper estimates the effects of tariffs on gross domestic product, exports, and employment across countries and sectors, using the Asian Development Bank's Multiregional Input-Output Tables. The 2018 trade conflict between the United States and the People's Republic of China presents a stumbling block to the global manufacturing and international trade that has driven growth and prosperity in Asia. Findings suggest that if all documented threats and retaliations were to be carried out, gross domestic product would fall by around $1 \%$ in the People's Republic of China and by $0.2 \%$ in the United States over a period of 2-3 years.

\section{About the Asian Development Bank}

ADB is committed to achieving a prosperous, inclusive, resilient, and sustainable Asia and the Pacific, while sustaining its efforts to eradicate extreme poverty. Established in 1966, it is owned by 67 members48 from the region. Its main instruments for helping its developing member countries are policy dialogue, loans, equity investments, guarantees, grants, and technical assistance. 